Article

\title{
Underground Barrier Wall Evaluation for Controlling Saltwater Intrusion in Sloping Unconfined Coastal Aquifers
}

\author{
Asaad M. Armanuos ${ }^{1}$ (D), Nadhir Al-Ansari ${ }^{2}\left(\mathbb{D}\right.$ and Zaher Mundher Yaseen ${ }^{3, *(1)}$ \\ 1 Irrigation and Hydraulics Engineering Department, Civil Engineering Department, Faculty of Engineering, \\ Tanta University, Tanta 31733, Egypt; asaad.matter@f-eng.tanta.edu.eg \\ 2 Civil, Environmental and Natural Resources Engineering, Lulea University of Technology, \\ 97187 Lulea, Sweden; nadhir.alansari@ltu.se \\ 3 Sustainable Developments in Civil Engineering Research Group, Faculty of Civil Engineering, \\ Ton Duc Thang University, Ho Chi Minh City, Vietnam \\ * Correspondence: yaseen@tdtu.edu.vn
}

Received: 9 July 2020; Accepted: 25 August 2020; Published: 27 August 2020

\begin{abstract}
Barrier walls are considered one of the most effective methods for facilitating the retreat of saltwater intrusion (SWI). This research plans to examine the effect of using barrier walls for controlling of SWI in sloped unconfined aquifers. The sloping unconfined aquifer is considered with three different bed slopes. The SEAWAT model is implemented to simulate the SWI. For model validation, the numerical results of the seawater wedge at steady state were compared with the analytical solution. Increasing the ratio of flow barrier depth $\left(\mathrm{d}_{\mathrm{b}} / \mathrm{d}\right)$ forced the saltwater interface to move seaward and increased the repulsion ratio (R). With a positive sloping bed, further embedding the barrier wall from 0.2 to 0.7 caused $\mathrm{R}$ to increase from $0.3 \%$ to $59 \%$, while it increased from $1.8 \%$ to $41.7 \%$ and from $3.4 \%$ to $46.9 \%$ in the case of negative and horizontal slopes, respectively. Embedding the barrier wall to $a d_{b} / d$ value of more than 0.4 achieved a greater $R$ value in the three bed-sloping cases. Installing the barrier wall near the saltwater side with greater depth contributed to the retreat of the SWI. With a negative bed slope, moving the barrier wall from $X_{b} / L_{o}=1.0$ toward the saltwater side $\left(X_{b} / L_{o}=0.2\right)$ increased $R$ from $7.21 \%$ to $68.75 \%$, whereas $R$ increased from $5.3 \%$ to $67 \%$ for the horizontal sloping bed and from $5.1 \%$ to $64 \%$ for the positive sloping bed. The numerical results for the Akrotiri coastal aquifer confirm that the embedment of the barrier wall significantly affects the controlling of SWI by increasing the repulsion ratio $(\mathrm{R})$ and decreasing the SWI length ratio $\left(\mathrm{L} / \mathrm{L}_{\mathrm{a}}\right)$. Cost-benefit analysis is recommended to determine the optimal design of barrier walls for increasing the cost-effectiveness of the application of barrier walls as a countermeasure for controlling and preventing SWI in sloped unconfined aquifers.
\end{abstract}

Keywords: saltwater intrusion; numerical modeling; embedment depth; barrier wall; coastal aquifer sustainability; groundwater pollution

\section{Introduction}

Water has a significant role for human beings. Unluckily, water has been deteriorating with respect to quantity and quality over time. The problems identified with the quantity and quality of water have been expanding everywhere throughout the world, including saltwater contamination. Consequently, issues identified with seawater contamination (as saltwater intrusion) have come to be a significant issue for human beings [1]. The groundwater abundance introduces its role as the major freshwater source to satisfy the need of the human population. Unluckily, the impact of urbanization and industrialization toward groundwater systems leads to groundwater contamination [2]. 
In general, the categorization of groundwater contamination sources is due to either natural or anthropogenic sources. The first category "natural sources" is related to the geological formations with shallow groundwater mass (the chemical interaction between water and rock in cold waters), infiltration process from the surface water bodies with low quality (rivers, canals, and lakes), saltwater intrusion, and impact of geothermal liquids (the interaction between water and rock in hot waters) [3]. The anthropogenic sources are mainly attributed to outrageous utilization of agricultural, pesticides, herbicides, wastes from mining activities, removal of wastes from industries, landfill sites, and imperfect well construction [4].

Seawater intrusion is one of the kinds of groundwater contamination [5]. The groundwater abstraction and human activities results in distribution of the balance naturally found in between the freshwater and saline water in the coastal aquifers. In addition, it minimizes the flow of freshwater to seaside and reduces the volume of freshwater. Further, saline water intrudes more into coastal aquifers, and as a result it becomes not accessible to use. The contamination of groundwater is basically brought about by human activities, particularly because of groundwater exploitation for settlement, shrimp cultivating, and the fisheries on the seashore [1]. Saltwater intrusion as a kind of groundwater contamination that happens in the interface among the groundwater and the saltwater [6]. The density of seawater is exceeding the freshwater, so the saline water pushes the freshwater in the groundwater system [2].

Among several freshwater sources, groundwater in coastal regions is one of the significant sources all around the globe. The development of regions near the shoreline of coastal areas, in addition to a limitation of surface water in these areas, increases the pressure on fresh groundwater $[7,8]$. In addition, abstraction from groundwater systems in coastal aquifers becomes essential to cover the demand, leading to groundwater level depletion and reduced groundwater flow to the sea $[9,10]$. As a result of that, saline water intrudes further inland into coastal aquifers [11,12]. Saltwater intrusion (SWI) deteriorates the groundwater quality, decreases fresh groundwater volume, and threatens the groundwater itself [13-17]. SWI is the major environmental problem in the systems of coastal aquifers $[18,19]$. The rise in the seawater level has an important effectiveness on the SWI process, as it accelerates the SWI degree. The IPCC has reported that the seawater level is expected to rise in a range from 0.52 to $0.98 \mathrm{~m}$ before the end of the current century [20,21]. Several studies have suggested different strategies for preventing or controlling the SWI in coastal aquifers [22-25]. These methods can be summarized as the following measures: (i) a decrease in groundwater abstraction [26,27], (ii) artificial recharge through recharge wells and spreading basins [28,29], (iii) freshwater injection in the coastal area to maintain the freshwater ridge [30-33], (iv) abstraction of saltwater along the coast [34,35], (v) construction of underground barriers [36,37], (vi) optimization of the rate of abstraction [38-40], (vii) land reclamation, and (viii) a combination of different techniques [41,42]. These approaches are described in the following paragraphs.

Anwar (1983) examined the impact of using cutoff walls to control seawater intrusion. An analytical solution was established according to the sharp interface approach to determine the saltwater interface location with the use of a cutoff wall [43]. The coefficient values in the analytical relationship were derived based on the laboratory experiments. Basri (2001) developed two new methods based on implicit and explicit simulation-optimizing methodologies to increase the cost-effectiveness of controlling SWI using an underground cutoff wall [44]. Several scholars have implemented laboratory experiments to investigate the effectiveness of installing barrier walls to control SWI [28,36,45-47]. Luyun et al. (2011) did experimental tests to investigate the use of underground barrier walls with different embedding depths and locations to control SWI [28]. The results showed that embedding the underground barrier wall more in the aquifer and nearer to the seawater side led to a retreat of SWI and an increase in repulsion ratio of saltwater intrusion (R). Allow (2012) utilized the SEAWAT code to simulate the consequence of using injection through wells or a subsurface flow barrier in controlling SWI in a Damsarkho (Latakia, Syria) coastal aquifer [48]. The results showed that using subsurface barriers or injection wells was effective in preventing SWI. Kaleris and Ziogas [46] implemented numerical 
simulations to investigate the effectiveness of a cutoff wall to control SWI and keep groundwater abstraction for a wide selection of wall geometries and aquifer hydraulic parameters. Designed charts and empirical formulas were presented for use in the field to assess the effectiveness of the flow barrier. Abdoulhalik and Ahmed (2017) implemented a numerical analysis and laboratory study on the control of SWI in aquifers with stratification [47]. Abdoulhalik et al. (2017) established a modern mixed flow barrier that combines a cutoff wall and a semi-pervious dam [45]. The established wall maintained the SWI transport to the seawater side and attained a significant repulsion ratio of SWI. Armanuos et al. (2019) implemented laboratory tests to investigate the effectiveness of using an underground barrier wall, freshwater injection through wells, and a combining together of methods to control the advancement of SWI [32]. Lu et al. (2016) used the Dupuit-Forchheimer approximation to develop an analytical solution to describe SWI in confined and unconfined sloped aquifers. The results confirmed that the SWI interface tip depended on the bed geometry layer [49]. Armanuos et al. (2020) utilized SEAWAT to explore the consequence of using freshwater recharge out of underground wells for controlling the SWI in unconfined sloped aquifers [33]. A sensitivity examination was accomplished to investigate the effect of changing the aquifer bed slope and hydraulic parameters on the repulsion ratio of SWI. The results confirmed that injection at the toe position achieved higher repulsion ratio values.

Underground physical barriers can be characterized as underground impermeable or semi-impermeable hydraulic structures built in the coastal aquifers to preserve groundwater, for saltwater prevention, increasing the freshwater volume, and increasing capacity of groundwater storage. Two types of underground physical barriers exist relying upon the opening area for the groundwater flow starting from the freshwater side to the coast [14]. Subsurface dams are considered underground storage dams including a base fixed on the foundation of the aquifer and an opening crest on the upper aquifer region. On the other hand, subsurface flow barriers are not implied for groundwater storage yet may essentially be physical barriers embedded throughout the direction of groundwater flow to change the flow. Subsurface flow barriers penetrated the aquifer partially and have openings below the barrier wall at the lower aquifer. Subsurface flow barriers are implied essentially to increase the groundwater level and control the saltwater intrusion. Underground dams were built in the Roman times by the ancient civilization in Sardinia and in the Northern area of Africa [50]. As of late, groundwater dams with small scale have been constructed in the Southern and the Eastern parts of Africa, India, Brazil and Japan. Japan has come to be the prominent supporter of underground dam innovation.

Prof. Kachi is considered the first researcher to suggest the full-scale of underground dam, which was constructed in Japan in the year of 1945, yet the first part of the built dam was not constructed until 1974, on Kabashima Island of the coastal area of Nagasaki [14]. The Kabashima underground dam was constructed with a $24.8 \mathrm{~m}$ height, its length at crest was $58.5 \mathrm{~m}$, and was introduced utilizing grouting techniques. From that time, the development of underground dams has improved increasingly. For example, in Miyakojima Island, the Fukuzato dam has a height of $70 \mathrm{~m}$, a crest length of $2.9 \mathrm{~km}$, and was constructed with a reservoir capacity excess of 10 million $\mathrm{m}^{3}$. There are currently around 15 underground dams constructed in Japan, seven of which were explicitly built to prevent and control SWI inland into coastal aquifer systems [14]. There is a shortage of data and evidence on current partially embedded underground flow barriers built for SWI control. Be that as it may, the advantages and disadvantages, the requirements of design might be patterned after subsurface dams.

The feasibility of a subsurface barrier relies on different geographical and hydrogeological factors. Subsurface dams are recommended to build in limited areas, where valleys lie beneath by an aquifer bedrock or formation with low conductivity. This diminishes the expenses of construction and makes it conceivable to evaluate the volume of storage and to control conceivable leakage losses. Hanson and Nilsson (1986) detailed that regions with slope range from 1 to 5\% are extremely practical [50]. Underground barriers are ideally built at sites with high permeability, for example, sand and gravel riverbeds, the zones of watershed, and deep alluvial layers. While the embedment of underground barriers includes subsurface works, the construction cost turns out to be genuinely high contrasted 
with different techniques. While numerous groundwater engineers accept that cost of construction is a significant restriction for construction of an underground barrier, engineers in Japan have prevailing research with regards to decreasing the expense by using advanced construction systems, for example, the soil mixing wall (SMW) or trench-cutting remixing deep wall (TRD) techniques for the construction of barrier walls. Over the long haul, low costs of operation may adjust the significant expense of underground barriers construction [14]. The Komesu concrete subsurface dam (cutoff wall) located in Japan, with length of $2320 \mathrm{~m}$, with width of $0.54 \mathrm{~m}$ and $70 \mathrm{~m}$ depth below the mean sea level, can be introduced as a good case for underground physical barriers constructed with a large scale for protecting a groundwater aquifer system from SWI.

The following sentences present the approximate bed slope values of different coastal aquifers according to published papers and reports: Nile Delta aquifer (Egypt) $0.30-0.40 \%$ [51], Cyprus aquifer (Carpus) 1.7\% [52]), Mediterranean aquifer (Mediterranean coastal area) 1.0\% [53], Gaza aquifer (Palestine) 1.33\% [54], Tripoli aquifer (Libya) 2.0-2.5\% [55], Buraydah aquifer (Saudi Arabia) 0.72\% [56], Laizhou bay aquifer (China) 0.27\% [57], Biscayne aquifer (USA) 0.0\% [58], Karst Coastal aquifer (Central Italy) 0.0\% [59], Gulf coastal aquifer (USA) 1.46\% [60], Ethiopian coastal aquifer (Ethiopia) 1.25\% [61], Maryland coastal aquifer (USA), 1.26\% [62], Germasogeia aquifer (Cyprus) 1.0\% [63], Ravenna aquifer (Italy) $0.1 \%$ [64], North Carolina aquifer (USA) $0.55 \%$ [65], and Hypothetical aquifer (from $-244 \%$ to $2 \%$ ) [49].

To the best knowledge of the current research, the reviewed literature studies did not investigate the effectiveness of using a barrier wall for controlling SWI in sloped unconfined aquifers and considered only horizontal aquifers. Therefore, the primary research aim of the current study is to evaluate the effect of using an underground barrier wall on the control of SWI in sloped unconfined aquifers.

\section{Materials and Methods}

\subsection{Numerical Modeling Approach}

In this research, SEAWAT code was applied to simulate the SWI interface and the repulsion of SWI interface after installing a barrier wall to control SWI. The utilized model was followed to established research by [66]. The main advantage of the SEAWAT model is that it can apply both MODFLOW and MT3DMS. In addition, it is capable of solving integrated formulations of groundwater and solute transport flow. Conceptually, it implements Variable Density Flow (VDF) computations. Based on the reported literature, SEAWAT has been extensively employed to solve different experimental problems (for example, see $[67,68]$ ). The following variable-density groundwater flow equation, in terms of the equivalent freshwater head, was solved by the (VDF) process in SEAWAT [66,69]:

$$
\nabla\left[\rho \times \frac{\mu_{0}}{\mu} \times K_{0}\left(\nabla \times h_{0}+\frac{\rho-\rho_{0}}{\rho_{0}} \times \nabla z\right)\right]=\rho \times S_{s, 0}\left(\frac{\partial h_{0}}{\partial t}\right)+\theta \times\left(\frac{\partial \rho}{\partial C}\right)\left(\frac{\partial C}{\partial t}\right)-\rho_{\mathrm{s}} \times q_{s}^{\prime}
$$

where $\rho_{0}$ is the density of fresh groundwater $\left(\mathrm{ML}^{-3}\right), \rho$ is the density of saline groundwater $\left(\mathrm{ML}^{-3}\right), \mu_{0}$ is the freshwater dynamic viscosity $\left(\mathrm{ML}^{-1} \mathrm{~T}^{-1}\right), \mu$ is the saline groundwater dynamic viscosity $\left(\mathrm{ML}^{-1} \mathrm{~T}^{-1}\right)$, $\mathrm{h}_{0}$ is the hydraulic groundwater head $(\mathrm{L}), \mathrm{S}_{\mathrm{s}, 0}$ is the specific storage $\left(\mathrm{L}^{-1}\right), \mathrm{K}_{0}$ is the hydraulic conductivity tensor of material saturated with the reference fluid $\left(\mathrm{LT}^{-1}\right), \mathrm{q}_{\mathrm{s}}^{\prime}$ is a source or sink $\left(\mathrm{T}^{-1}\right)$ of fluid with a density of $\rho_{\mathrm{S}}, \theta$ is the porosity $\left(\mathrm{M}^{0} \mathrm{~L}^{0} \mathrm{~T}^{0}\right)$, $\mathrm{t}$ is the time $(\mathrm{T})$, and $\mathrm{C}$ is the salt concentration $\left(\mathrm{ML}^{-3}\right)$.

The Integrated MT3DMS Transport (IMT) process in the SEAWAT program solves the following solute transport equation [69]:

$$
\left(1+\frac{\rho_{\mathrm{b}} \times \mathrm{K}_{\mathrm{d}}^{\mathrm{k}}}{\theta}\right) \frac{\partial\left(\theta \times \mathrm{C}^{\mathrm{k}}\right)}{\partial \mathrm{t}}=\nabla\left(\theta \mathrm{D} \times \nabla \mathrm{C}^{\mathrm{k}}\right)-\nabla\left(\mathrm{q} \times \mathrm{C}^{\mathrm{k}}\right)-\left({ }_{\mathrm{q}}^{\prime} \times \mathrm{C}_{\mathrm{s}}^{\mathrm{k}}\right)
$$

where $\theta$ is the porosity $\left(\mathrm{M}^{0} \mathrm{~L}^{0} \mathrm{~T}^{0}\right), \mathrm{C}^{\mathrm{k}}$ is the concentration of species $\mathrm{k}\left(\mathrm{ML}^{-3}\right), \mathrm{q}_{\mathrm{s}}^{\prime}$ is a source or a sink $\left(\mathrm{T}^{-1}\right)$ of a fluid with a density of $\rho_{\mathrm{s}}\left(\mathrm{ML}^{-3}\right), \rho_{\mathrm{b}}$ is the bulk density $\left(\mathrm{ML}^{-3}\right), \mathrm{K}_{\mathrm{d}}^{\mathrm{k}}$ is the value of distribution 
coefficient of species $\mathrm{k}\left(\mathrm{L}^{3} \mathrm{M}^{-1}\right)$, $\mathrm{D}$ is the value of hydrodynamic dispersion coefficient $\left(\mathrm{L}^{2} \mathrm{~T}^{-1}\right), \mathrm{q}$ is the value of specific discharge $\left(\mathrm{LT}^{-1}\right)$, and $\mathrm{C}_{\mathrm{s}}^{\mathrm{k}}$ is the value of source or sink concentration of species $\mathrm{k}$ $\left(\mathrm{ML}^{-3}\right)$.

\subsection{Sloping Unconfined Coastal Aquifer}

In this study, the sloping unconfined aquifer by [49] was utilized to investigate the effect of using a barrier wall for controlling the SWI in an unconfined sloped aquifer. Figure 1 shows the sloping unconfined coastal aquifer and boundary conditions. The dimensions of model cell were set to $\Delta \mathrm{x}=\Delta \mathrm{y}=1.0 \mathrm{~m}$. The defined dispersivity in longitudinal and transverse directions was 1.0 and $0.10 \mathrm{~m}$, respectively. Three values of sloping bed $(\tan \beta)$ were studied: $0.02,0.0$, and -0.02 for positive, horizontal, and negative slops, respectively. The defined seawater head $\left(h_{s}\right)$ was $40.0 \mathrm{~m}$, and the freshwater head $\left(\mathrm{h}_{\mathrm{f}}\right)$ was defined in a variety from 41.50 to $43.00 \mathrm{~m}$ with a step of $0.50 \mathrm{~m}$. The defined density for the freshwater head boundary was $1000 \mathrm{~kg} / \mathrm{m}^{3}$ with a constant salt concentration equal to zero. The defined density for the seawater head boundary was $1025 \mathrm{~kg} / \mathrm{m}^{3}$ with a constant salt concentration equal to $35,000 \mathrm{mg} / \mathrm{L}$. The defined hydraulic conductivity was $10 \mathrm{~m} /$ day in all directions, where the domain was assumed to be a homogenous and isotropic aquifer. The defined porosity is 0.43 . The parameters descriptions of the studied case are shown in Table 1, and the defined parameters of SEAWAT are presented in Table 2.

Table 1. Parameter definitions.

\begin{tabular}{cc}
\hline Parameter & Definition \\
\hline$d$ & Aquifer depth \\
$L_{a}$ & Aquifer length \\
$L_{o}$ & The length of $S W I$ wedge after embedding the barrier wall \\
$L$ & SWI length ratio \\
$L^{2} L_{a}$ & The repulsion ratio $R=\left(\mathrm{L}_{\mathrm{o}}-\mathrm{L}\right) / \mathrm{L}_{\mathrm{o}}$ \\
$\mathrm{R}$ & The wall distance ratio \\
$\mathrm{X}_{\mathrm{b}}$ & The wall depth \\
$\mathrm{X}_{\mathrm{b}} / \mathrm{L}_{\mathrm{o}}$ & Bed slope value of the aquifer \\
$\mathrm{d}_{\mathrm{b}}$ & The wall depth ratio \\
$\mathrm{Tan}_{\beta}$ & The defined head of saltwater \\
$\mathrm{d}_{\mathrm{b}} / \mathrm{d}$ & The defined head of freshwater \\
$\mathrm{h}_{\mathrm{s}}$ & Hydraulic gradient \\
$\mathrm{h}_{\mathrm{f}}$ & The defined density of freshwater \\
$\mathrm{i}$ & The defined density of saltwater \\
$\rho_{\mathrm{f}}$ & The defined Hydraulic conductivity \\
$\rho_{\mathrm{s}}$ &
\end{tabular}

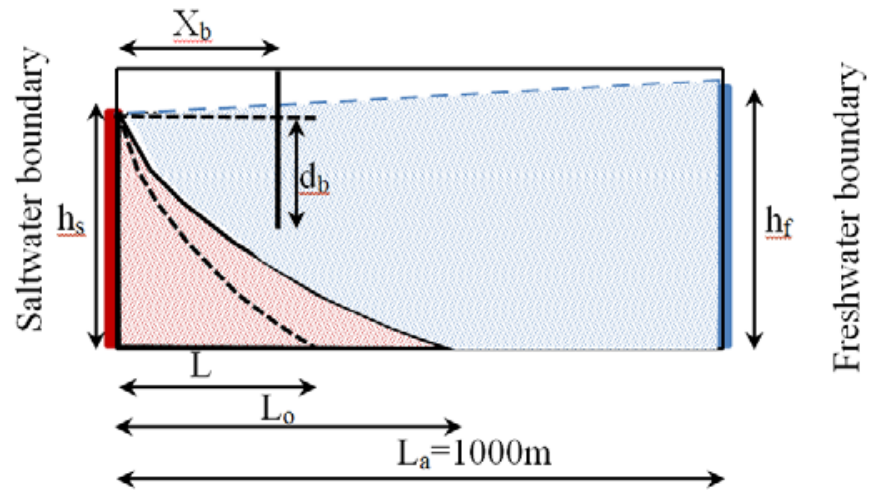

(a)

Figure 1. Cont. 


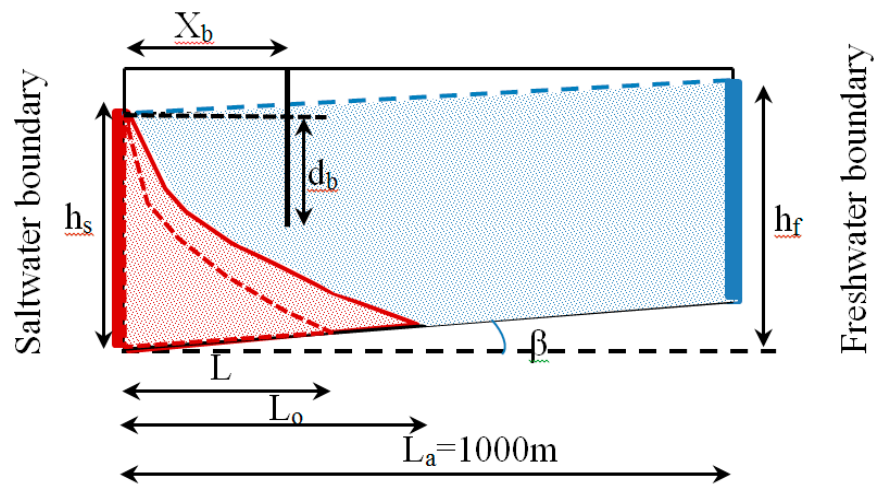

(b)

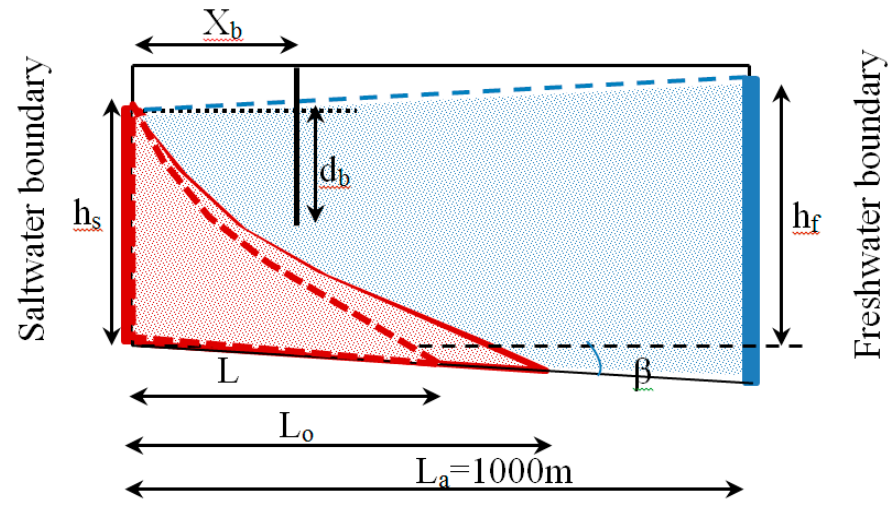

(c)

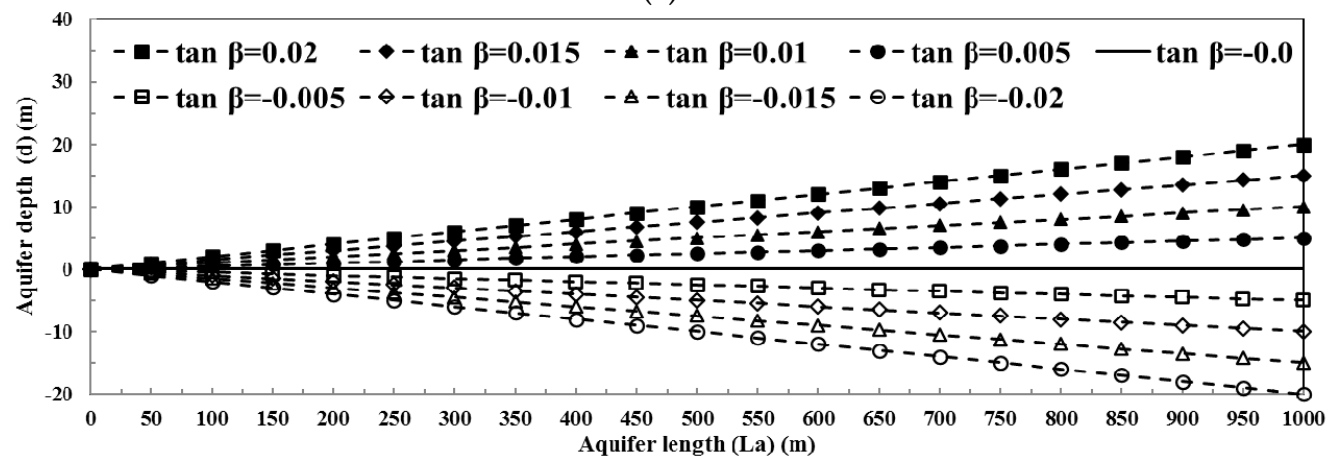

(d)

Figure 1. Dimensions and specifications of the hypothetical unconfined aquifer: (a) Horizontal aquifer; (b) positive sloping; (c) negative sloping; (d) sloping bed values of the unconfined aquifer.

Table 2. Input parameters for numerical simulation of the flow barrier.

\begin{tabular}{cc}
\hline Input Parameter & Values \\
\hline Domain length & $1000 \mathrm{~m}$ \\
Domain height & $45.0 \mathrm{~m}$ \\
Porosity & 0.43 \\
Freshwater head & $41.50 \mathrm{~m}$ \\
Saltwater head & $40.00 \mathrm{~m}$ \\
Aquifer length & $1000 \mathrm{~m}$ \\
Freshwater density & $1000 \mathrm{~kg} / \mathrm{m}^{3}$ \\
Saltwater density & $1025 \mathrm{~kg} / \mathrm{m}^{3}$ \\
Freshwater concentration & $0.0 \mathrm{mg} / \mathrm{L}$ \\
Saltwater concentration & $35,000 \mathrm{mg} / \mathrm{L}$ \\
Hydraulic conductivity & $10 \mathrm{~m} / \mathrm{day}$ \\
\hline
\end{tabular}


Table 2. Cont.

\begin{tabular}{cc}
\hline Input Parameter & Values \\
\hline Longitudinal dispersivity & $1.0 \mathrm{~m}$ \\
Transverse dispersivity & $0.1 \mathrm{~m}$ \\
Molecular diffusion coefficient & $1 \times 10^{-6} \mathrm{~cm}^{2} / \mathrm{s}$ \\
Cell size & $2.0 \times 2.0 \mathrm{~m}$ \\
Solution of the flow equation & \\
Matrix solution techniques & (Pre-conditioned Conjugate-Gradient) PCG \\
The value of head convergence & $1 \times 10^{-7} \mathrm{~m}$ \\
The value of flow convergence & $1 \times 10^{-7} \mathrm{~kg} /$ day \\
Advection term & 0.10 \\
Courant number & (Third-order total variation diminishing) TVD \\
Dispersion and source terms & (Generalized Conjugate-Gradient) GCG \\
The value of concentration convergence & $1 \times 10^{-7}$ \\
\hline
\end{tabular}

The SEAWAT code was initially calibrated by comparing the SWI interface of the analytical solution with that of the numerical one (SEAWAT model) for the following two cases, which were presented in [49]. The first case was a positive sloping unconfined aquifer with $\tan \beta=0.02, \mathrm{~h}_{\mathrm{s}}=40.0 \mathrm{~m}$, and three different values for the freshwater head: $h_{f}=41.50,42.0$, and $42.50 \mathrm{~m}$. The second case was a negative sloping unconfined aquifer with $\tan \beta=-0.02, \mathrm{~h}_{\mathrm{s}}=40.0 \mathrm{~m}$, and three different values for the freshwater head: $h_{f}=41.50,42.0$ and $42.50 \mathrm{~m}$. The correlation coefficient and RMSE value were computed to compare the SWI interface in the numerical results with that in the analytical solutions $[17,70]$. The values of the simulation parameters used to study the sensitivity of the hydraulic parameters and barrier wall parameters are shown in Tables 3 and 4, respectively.

Table 3. Tested numerical simulation range of hydraulic parameters to test the effect on saltwater intrusion (SWI) length.

\begin{tabular}{cc}
\hline Parameters & Range \\
\hline Bed slope: $\tan \beta$ & Negative slope: $-0.02,-0.015$ and -0.01 \\
Horizontal slope: 0.0
\end{tabular}

Table 4. Tested numerical simulation range of hydraulic parameters to test the effects on the repulsion ratio $\mathrm{R}$.

\begin{tabular}{cc}
\hline Parameter & Range \\
\hline Bed slope: $\tan \beta$ & $\begin{array}{c}\text { Negative: }-0.02 \\
\text { Horizontal: } 0.0 \\
\text { Positive: } 0.02\end{array}$ \\
\hline Hydraulic conductivity $\mathrm{K}$ & $\begin{array}{c}10,15,20 \text { and } 25 \mathrm{~m} / \text { day } \\
40.00 \mathrm{~m}\end{array}$ \\
Head of saltwater $\mathrm{h}_{\mathrm{f}}$ & $41.50,41.75,42.00,42.25,42.50,42.75$ and $43.00 \mathrm{~m}$ \\
Head of Freshwater $\mathrm{h}_{\mathrm{s}}$ & $0.0015(1.5 / 1000), 0.00175(1.75 / 1000), 0.002(2.00 / 1000), 0.00225$ \\
Hydraulic gradient $\mathrm{i}$ & $(2.25 / 1000), 0.0025(2.50 / 1000), 0.00275(2.75 / 1000)$ and $0.003(3.00 / 1000)$ \\
Saltwater density $\rho_{\mathrm{s}}$ & $1022,1025,1027$ and $1030 \mathrm{~kg} / \mathrm{m}^{3}$ with defined salt concentration $\left(\mathrm{C}_{\mathrm{s}}\right)$ \\
Barrier wall depth ratio $\mathrm{d}_{\mathrm{b}} / \mathrm{d}$ & equal to $30,000,35,000,37,500$ and $40,000 \mathrm{mg} / \mathrm{L}$, accordingly \\
Barrier wall distance ratio $\mathrm{X}_{\mathrm{b}} / \mathrm{L}_{\mathrm{o}}$ & $0.2,0.3,0.4,0.5,0.6,0.7$ and 0.8 \\
\end{tabular}




\subsection{Model Calibration}

Figure 2a compares the results of the analytical and numerical SWI interfaces for the positive sloping bed unconfined aquifer $(\tan \beta=0.02)$. The analytical results of SWI length in the steady state were 280, 225 and $185 \mathrm{~m}$ for a freshwater head of 41.50, 42.0 and $42.50 \mathrm{~m}$, compared with 265, 220 and $175 \mathrm{~m}$ correspondingly in the numerical solution, as shown in Figure 2a. The comparison between analytical and numerical results depicts a good agreement, with correlation coefficients equal to $0.995,0.993$ and 0.998 and RMSE equal to $1.93,1.76$ and $1.54 \mathrm{~m}$ for $\mathrm{h}_{\mathrm{f}}$ equal to $41.50,42.0$ and $42.50 \mathrm{~m}$, respectively. Figure $2 \mathrm{~b}$ displays the relationship among the analytical and SEAWAT outcomes for the steady-state SWI wedge interface for an unconfined aquifer with a negative sloping bed $(\tan \beta=-0.02)$. The lengths of the SWI wedge in the analytical solution were 622, 285 and $205 \mathrm{~m}$, while the corresponding lengths in the numerical results were 525, 275 and $200 \mathrm{~m}$, as shown in Figure $2 \mathrm{~b}$. The comparison between numerical and analytical solutions shows a good agreement, with correlation coefficients equal to $0.948,0.991$ and 0.995 and RMSEs equal to 4.52, 1.73 and $1.33 \mathrm{~m}$ for $h_{\mathrm{f}}$ equal to $41.50,42.0$ and $42.50 \mathrm{~m}$, respectively.

(a)

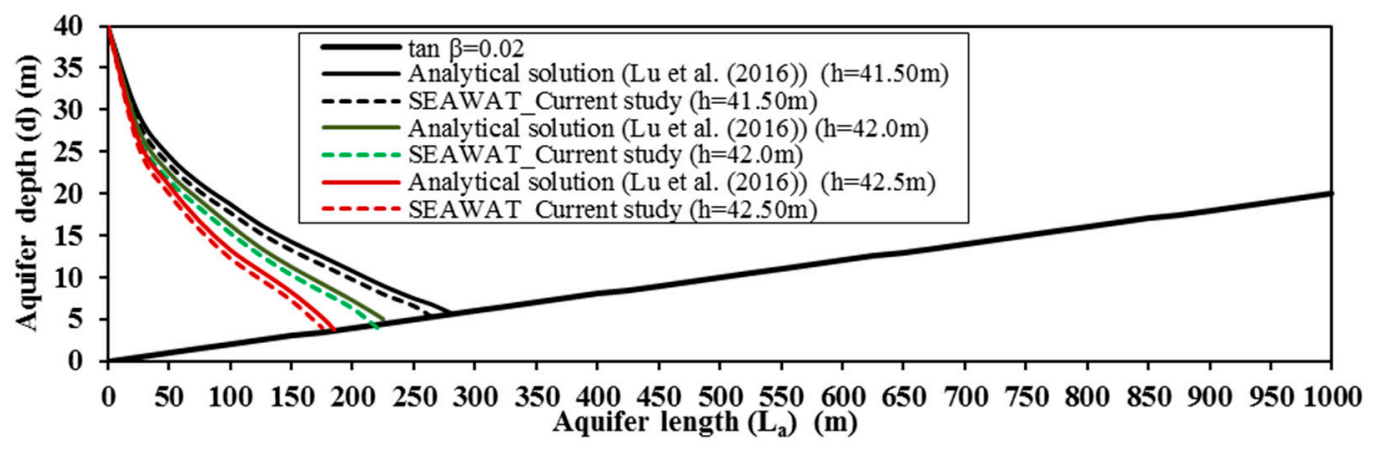

(b)

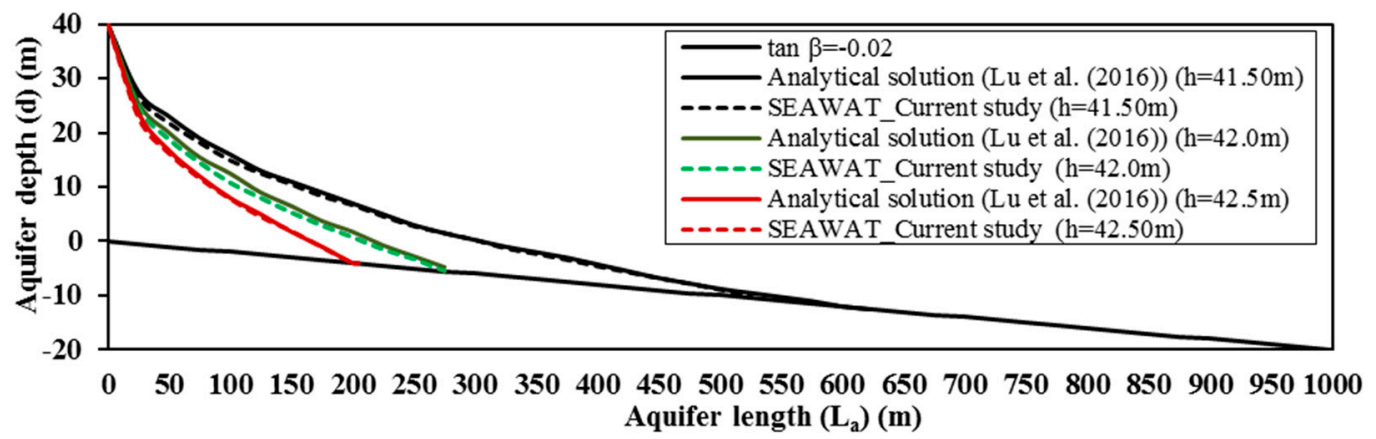

Figure 2. Comparison between the analytical and numerical results (SEAWAT) for the SWI interface in the steady state for a sloping bed unconfined aquifer: (a) positive sloping bed $(\tan \beta=0.02)$ and (b) negative sloping bed $(\tan \beta=-0.02)[49]$.

\section{Results and Discussion}

\subsection{Sensitivity Analysis of the Effect of Hydraulic Parameters on SWI Length}

3.1.1. The Impact of the Hydraulic Gradient (i) on the SWI Length Ratio in Sloping Unconfined Aquifers

In this part, a sensitivity analysis of the SWI length ratio resulting from variations in the hydraulic gradient was performed for seven different values of the hydraulic gradient $(0.0015,0.00175,0.002$, $0.00225,0.0025,0.00275$ and 0.003$)$, along with five different unconfined aquifer slope values $(0.02 \%$, $0.01 \%, 0.0 \%,-0.01 \%$ and $-0.02 \%$ ). Increasing the hydraulic gradient led to a decrease in the SWI length ratio. In the case of negative tan $\beta$ equal to -0.02 , the SWI length ratio decreased from $52.4 \%$ to $16.4 \%$ when the i value increased from 0.0015 to 0.003 . The effect of the hydraulic gradient on the SWI length 
ratio was less significant for positive values of $\tan \beta$. The decrease in the SWI length ratio was smaller (from $26.4 \%$ to $16.4 \%$ ) for a positive value of $\tan \beta$ equal to 0.02 than that for a negative slope of -0.02 (see Figure 3a). In comparison with a horizontal unconfined aquifer bed slope, negative values of $\tan \beta$ led to further movement inland of the SWI interface, while positive values of $\tan \beta$ caused the saltwater interface to be pushed more seaward.

\subsubsection{The Impact of Bed Slope on the SWI Length Ratio in Sloping Unconfined Aquifers}

In this analysis, the impact of the unconfined aquifer bed slope $\tan \beta$ on the SWI length ratio was explored for seven different bed slopes $(-0.02,-0.015,-0.01,0.0,0.01,0.015$ and 0.02$)$, with five different hydraulic gradient values $(0.0015,0.00175,0.002,0.00225$ and 0.0025$)$ (Figure $3 b)$. The SWI intruded into the aquifer further inland in the case of negative values and positive values of $\tan \beta$ compared with a horizontal slope. Decreasing tan $\beta$ from 0.02 to -0.02 cause the SWI to advance more inland in the aquifer, and the SWI length ratio increased from $26.4 \%$ to $52.4 \%$ when the hydraulic gradient was equal to 0.0015 . In addition, for the highest value of the hydraulic gradient (0.0025), the saltwater intruded less inland when $\mathrm{L} / \mathrm{L}_{\mathrm{a}}$ decreased to $17.6 \%$, as shown in Figure $3 \mathrm{~b}$.

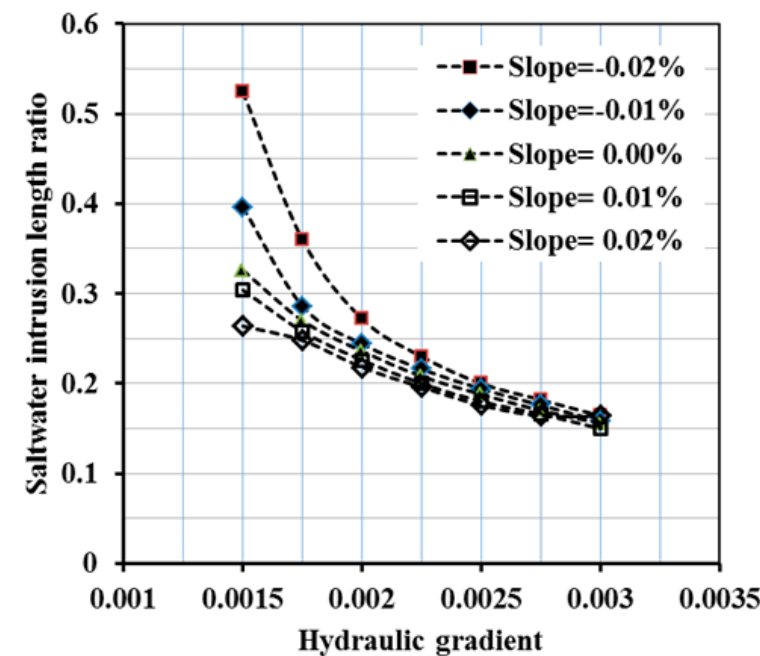

(a)

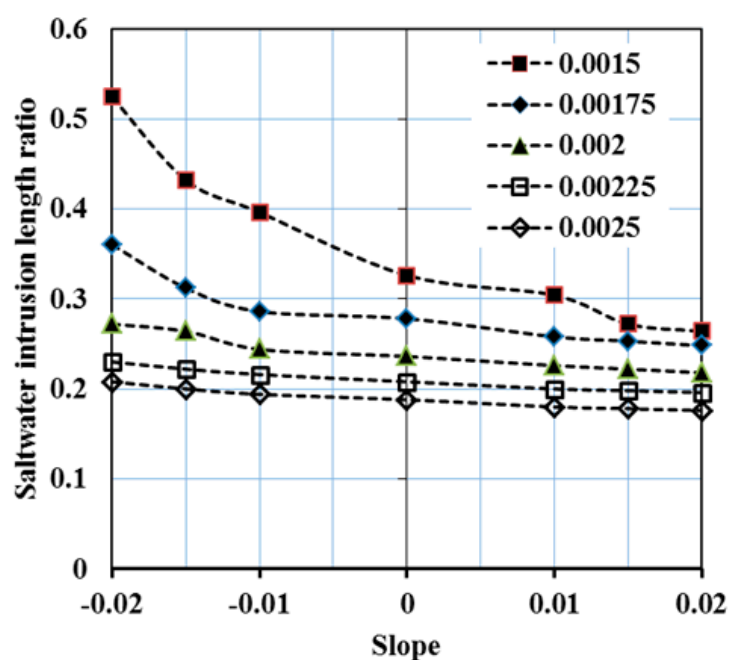

(b)

Figure 3. Relationship between (a) the hydraulic gradient and SWI length ratio and (b) the bed slope and SWI length ratio.

3.1.3. The Impact of Hydraulic Conductivity (K) on the SWI Length Ratio in Sloping Unconfined Aquifers

The impact of $(\mathrm{K})$ on the SWI length ratio was tested for four K values (10, 15, 20 and $25 \mathrm{~m} /$ day) and for seven values of the hydraulic gradient $(0.0015,0.00175,0.0020,0.00225,0.0025,0.00275$ and 0.003) (Figure 4). Three different bed slope values for the unconfined aquifer $(0.02,0.0$ and -0.02$)$ were considered. Increasing the values of hydraulic conductivity caused the seawater to move more toward the aquifer. For an unconfined aquifer, the ratio of the SWI length increased more for a negative $\tan \beta$ value equal to -0.02 compared with horizontal and positive slopes $(0.00$ and 0.02$)$, as shown in Figure $4 \mathrm{a}, \mathrm{b}$. In the case of a positive slope $(0.02 \%)$, increasing $\mathrm{K}$ from 10 to $25 \mathrm{~m} /$ day caused the $\mathrm{L} / \mathrm{L}_{\mathrm{a}}$ ratio to increase from $26.4 \%$ to $30.0 \%$ with $\mathrm{i}=0.0015$ and from $15 \%$ to $23 \%$ in case of $\mathrm{i}=0.002$. Moreover, the highest value of the $\mathrm{L} / \mathrm{L}_{\mathrm{a}}$ ratio was observed in the case of negative tan $\beta$ equal to -0.02 , where $\mathrm{L} / \mathrm{L}_{\mathrm{a}}$ increased from $52.4 \%$ to $62.4 \%$ when $\mathrm{K}$ was changed from 10 to $25 \mathrm{~m} /$ day in the case of $\mathrm{i}=0.0015$, as shown in Figure $4 \mathrm{c}$. 


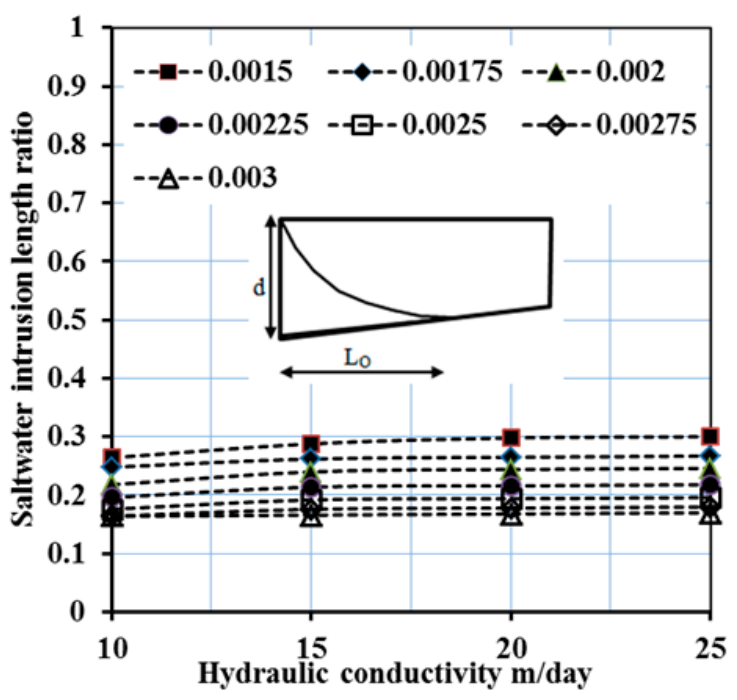

(a)

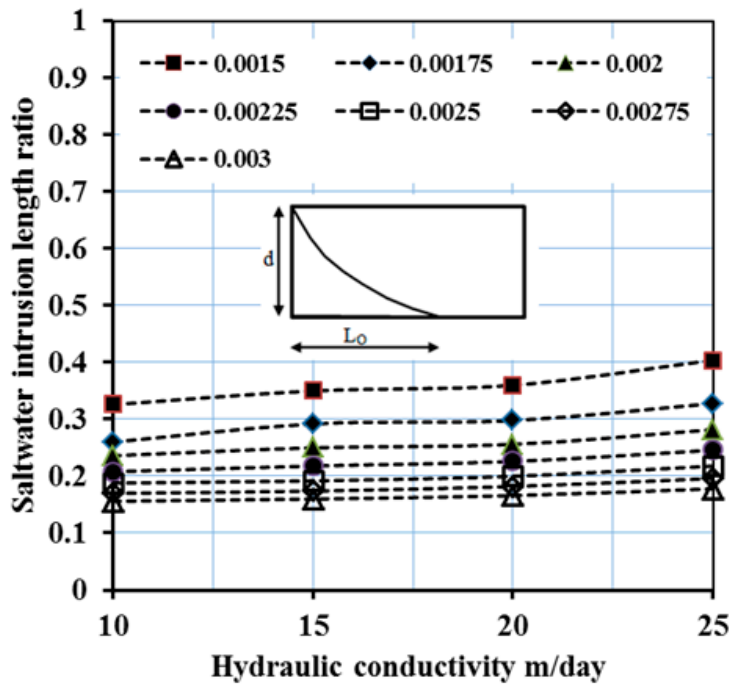

(b)

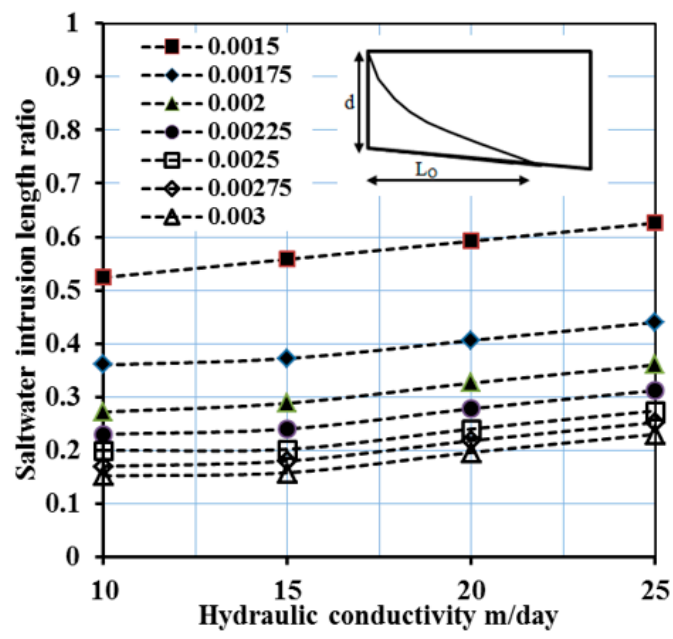

(c)

Figure 4. Relationship between hydraulic conductivity and SWI length ratio for $\tan \beta$ : (a) $\tan \beta=0.02$, (b) $\tan \beta=0.0$, and (c) $\tan \beta=-0.02$.

\subsubsection{The Impact of Saltwater Density on the SWI Length Ratio in Sloping Unconfined Aquifers}

To visualize the impact of saltwater density on the SWI length ratio, four values of saltwater density were tested. This was done for seven different hydraulic gradient values $(0.0015,0.00175$, $0.002,0.00225,0.0025,0.00275$ and 0.003$)$ and for three values of unconfined aquifer bed slopes tan $\beta$ $(0.02,0.00$ and -0.02$)$, as demonstrated in Figure 5. The SWI length ratio increased with the increase in saltwater density and concentration. For an unconfined aquifer, the negative value of the bed slope led to more inland migration of SWI with high density compared with a horizontal bed and positive slopes, as shown in Figure 5a,b. Increasing $\rho_{\mathrm{s}}$ from 1022 to $1030 \mathrm{~kg} / \mathrm{m}^{3}$ caused the SWI to further intrude into the unconfined aquifer, where the SWI length ratio increased from $33.4 \%$ to $100 \%$ with a low hydraulic gradient value (equal to 0.0015), and the aquifer became fully intruded with a negative bed slope, as shown in Figure 5c. In the case of tan $\beta$ equal zero, the SWI length ratio increased from $28.4 \%$ to $40 \%$ with a hydraulic gradient equal to 0.0015 , as shown in Figure $5 \mathrm{~b}$. On the other hand, the SWI length ratio decreased with a hydraulic gradient of 0.003 , whereas it increased from $12.8 \%$ to $18 \%$ when $\rho_{\mathrm{s}}$ increased from 1022 to $1030 \mathrm{~kg} / \mathrm{m}^{3}$, respectively. 


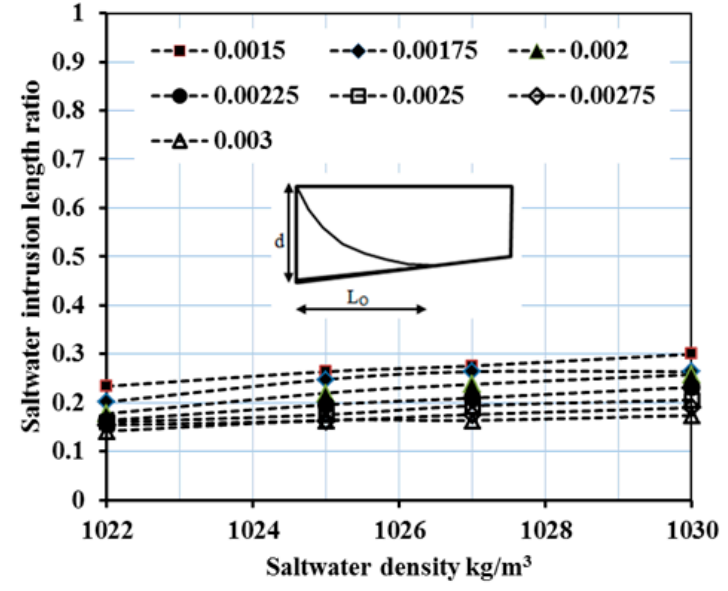

(a)

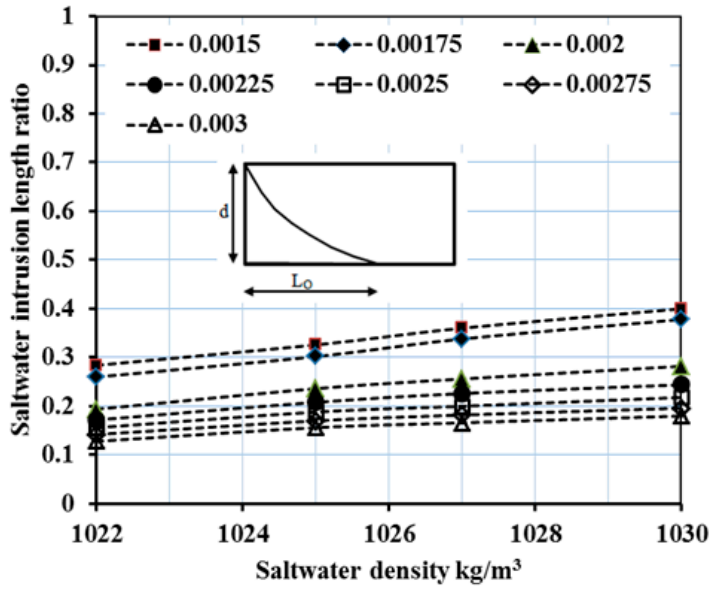

(b)

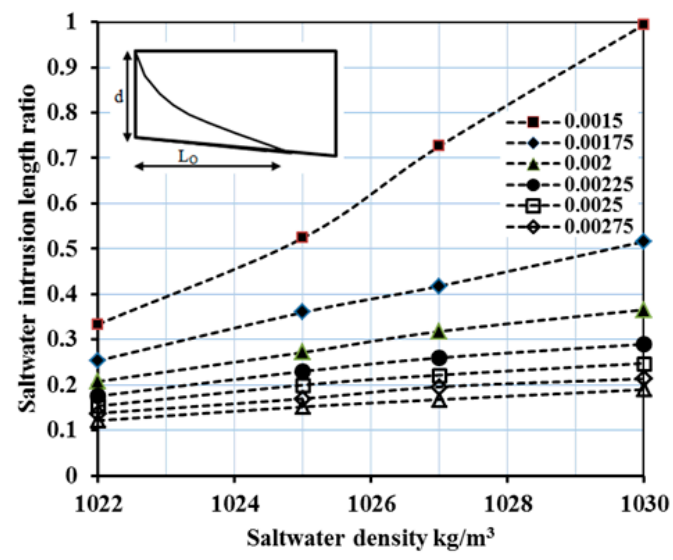

(c)

Figure 5. Relationship between saltwater density and SWI length ratio for (a) $\tan \beta=0.02$, (b) $\tan \beta=0.0$, and (c) $\tan \beta=-0.02$.

\subsection{Sensitivity Analysis of Hydraulic Parameters on the Repulsion Ratio (R)}

3.2.1. The Impact of Barrier Wall Distance on the Repulsion Ratio (R) in Sloping Unconfined Aquifers

In this part, a sensitivity analysis of variations in the repulsion ratio $(\mathrm{R})$ in response to the distance ratio of the wall $\mathrm{X}_{\mathrm{b}} / \mathrm{L}_{\mathrm{o}}$ was performed for five various location ratios $(0.2,0.4,0.6,0.8$ and 1.0). This was done for six different barrier depth ratios $\left(\mathrm{d}_{\mathrm{b}} / \mathrm{d}=0.2,0.3,0.4,0.5,0.6\right.$ and 0.7$)$. The fixed values were $\mathrm{K}$ $=10 \mathrm{~m} /$ day, $\rho_{\mathrm{s}}=1,025 \mathrm{~kg} / \mathrm{m}^{3}, \mathrm{C}_{\mathrm{s}}=35,000 \mathrm{mg} / \mathrm{L}$, and $\mathrm{i}=0.0025$ for three different bed slopes $\tan \beta$ of the unconfined aquifer $(0.02,0.0$ and -0.02$)$ (Figure 6). Decreasing the barrier wall distance ratio $X_{b} / L_{o}$ led to a reduction in the SWI and a rise in the R ratio. In the case of the negative bed slope, installing the wall near the seawater part achieved a higher repulsion ratio compared with horizontal and positive bed slopes. With respect to $d_{b} / d$ ratio, a combination of small $d_{b} / d$ and a higher value of $d_{b} / d$ caused the saltwater to retreat more to the seaside and caused the ratio $\mathrm{R}$ to increase. In the case of the negative bed slope aquifer, $\mathrm{R}$ decreased from $68.75 \%$ to $7.21 \%$ when the barrier wall distance ratio increased from 0.2 to 1.0 , and these values decreased from $67.0 \%$ to $5.3 \%$ and from $64 \%$ to $5.1 \%$ for horizontal and positive slopes, respectively, as shown in Figure $6 \mathrm{a}, \mathrm{b}$. In addition, embedding the barrier wall with a ratio ranging from 0.2 to 0.4 achieved an $\mathrm{R}$ of below $20 \%$ for all barrier wall locations, as shown in Figure 6. 


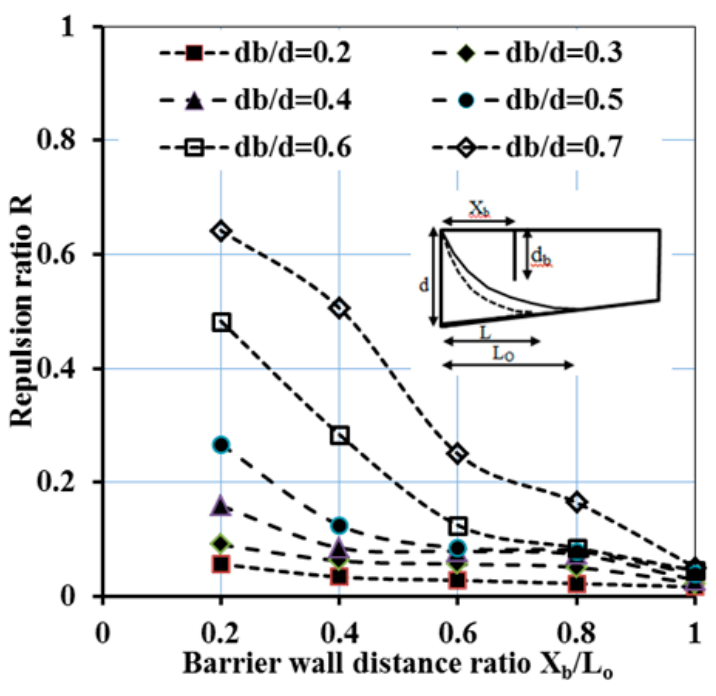

(a)

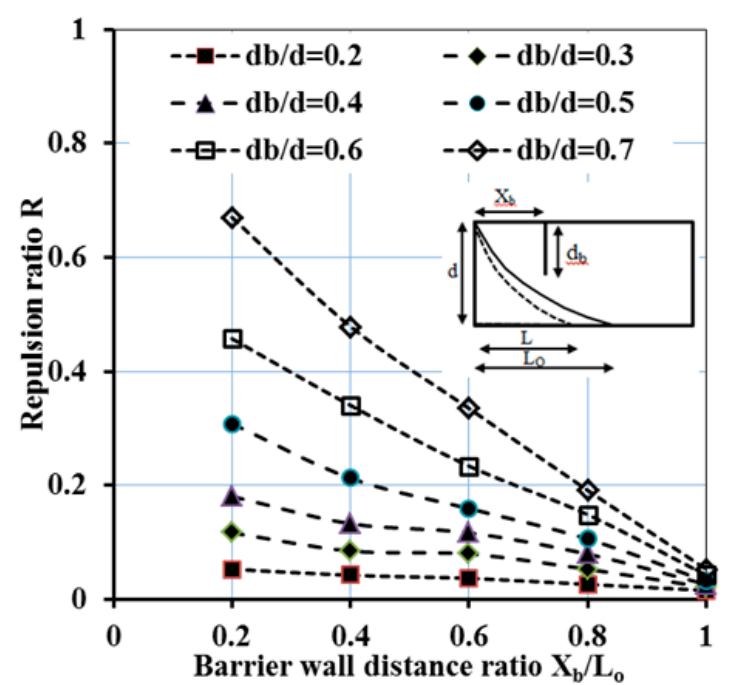

(b)

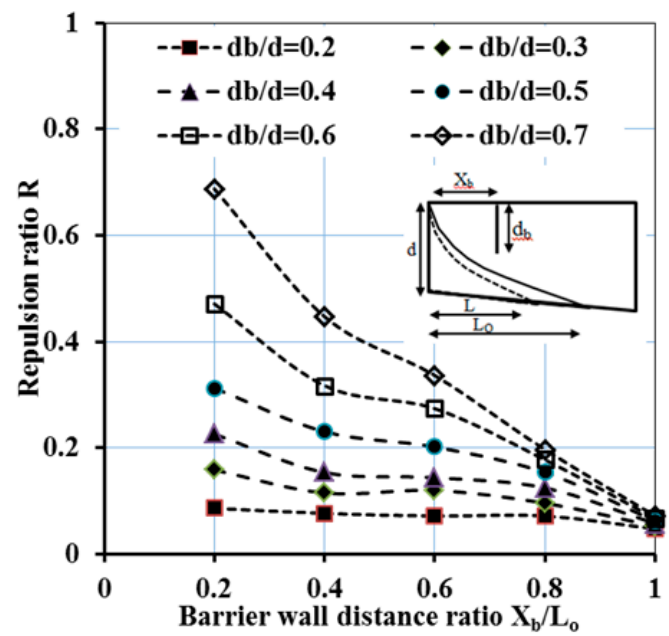

(c)

Figure 6. Relationship between the barrier wall distance ratio and $R$ for different bed slopes $\tan \beta$ :

(a) 0.02 , (b) 0.0, and (c) -0.02 .

3.2.2. The Impact of the Barrier Wall Depth Ratio on the Repulsion Ratio $(\mathrm{R})$ in Sloping Unconfined Aquifers

In this part, the sensitivity of $d_{b} / d$ on $R$ was tested for six various ratios of $d_{b} / d$ (Table 4 ) (Figure 7) with fixed values of $K=10 \mathrm{~m} /$ day, $\rho_{\mathrm{s}}=1025 \mathrm{~kg} / \mathrm{m}^{3}, \mathrm{C}_{\mathrm{s}}=35,000 \mathrm{mg} / \mathrm{L}$, and $\mathrm{i}=0.0015$ for five barrier wall depth ratios $\left(X_{b} / L_{o}=0.20,0.4,0.6,0.8\right.$ and 1.0) and for three bed slope values $(\tan \beta=0.02$, 0.0 , and -0.02). Increasing $d_{b} / d$ forced the seawater interface to retreat further to the seawater side. With increasing $d_{b} / d$, the SWI wedge length decreased, and the R ratio increased. A positive bed slope achieved a greater $\mathrm{R}$ compared with that obtained with horizontal and negative bed slopes. With respect to the wall location, embedding the wall near the seaside forced the seawater to attenuate back toward the seaside and achieved higher repulsion ratio values. In the case of a positive bed slope, the R increased from $0.30 \%$ to $59.0 \%$ when the barrier wall was installed more towards the aquifer and when $d_{b} / d$ increased from 0.2 to 0.70 , as shown in Figure 7a. Moreover, in the case of negative and horizontal slopes, R increased from $1.8 \%$ to $41.7 \%$ and from 3.4 to $46.9 \%$, respectively, as shown in Figure $7 \mathrm{~b}, \mathrm{c}$. When increasing $\mathrm{X}_{\mathrm{b}} / \mathrm{L}_{\mathrm{o}}$ to 1.0 , no repulsion of SWI was observed in the case of positive and horizontal slopes; only a negative slope achieved lower values of $R$. 


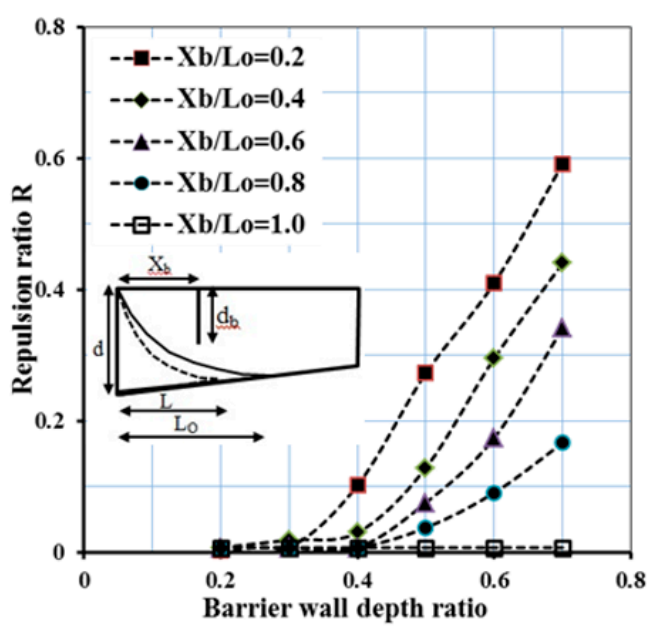

(a)

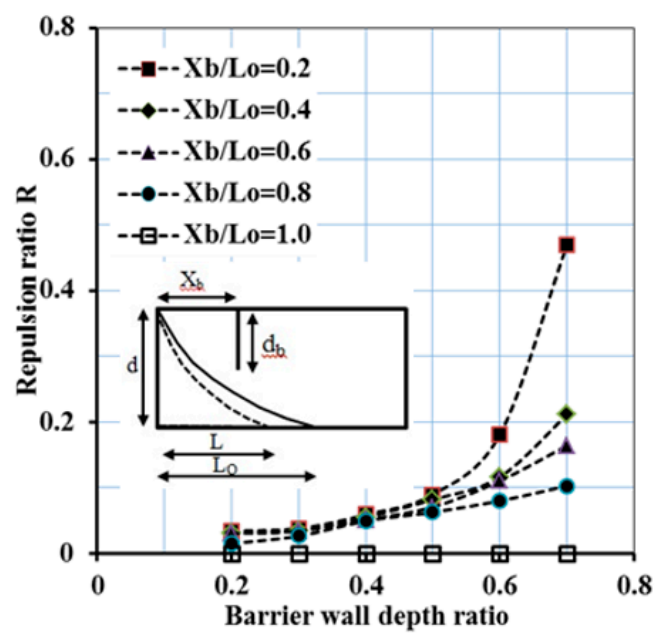

(b)

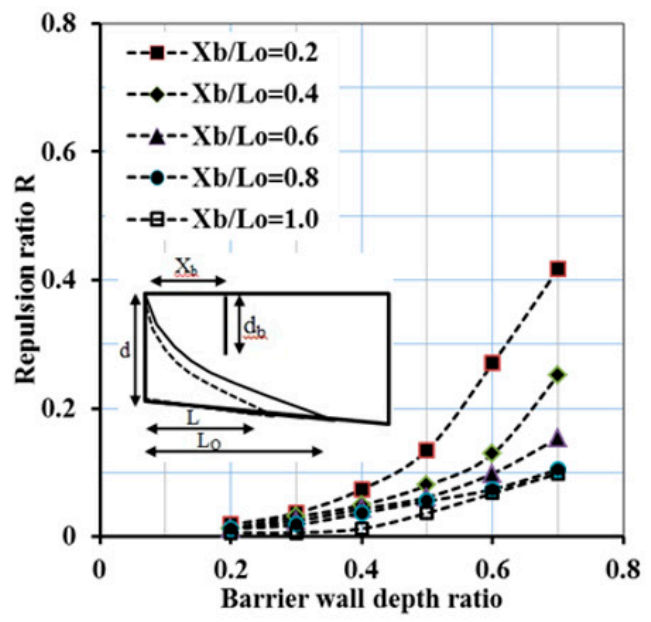

(c)

Figure 7. Relationship between the barrier wall depth ratio and $\mathrm{R}$ for $(\mathbf{a}) \tan \beta=0.02$, (b) $\tan \beta=0.0$, and (c) $\tan \beta=-0.02$.

\subsubsection{The Effect of Hydraulic Conductivity (K) on the (R) Ratio in Sloping Unconfined Aquifers}

The impact of $\mathrm{K}$ on $\mathrm{R}$ was explored for four various $\mathrm{K}$ values (10, 15, 20 and $25 \mathrm{~m} /$ day) (Figure 8); the fixed values were the barrier wall distance ratio $X_{b} / L_{o}=0.2, \rho_{s}=1025 \mathrm{~kg} / \mathrm{m}^{3}, C_{s}=35,000 \mathrm{mg} / \mathrm{L}$, and $i=0.0025$. This was performed for six different barrier wall depths $\left(\mathrm{d}_{\mathrm{b}} / \mathrm{d}=0.2,0.3,0.4,0.5,0.6\right.$ and 0.7$)$ and three different bed aquifer slopes $\tan \beta(0.02,0.0$ and -0.02$)$. Increasing the value of $K$ caused the saline water to advance more into the aquifer and decreased the value of $R$. With respect to the bed slope of the unconfined aquifer, placing the barrier wall through the aquifer with a positive value of $\tan \beta$ had a significantly greater impact compared with horizontal and negative slopes. Embedding the barrier wall with a high ratio $d_{b} / d$ and low values of $K$ increased the value of the ratio $R$, and the seawater interface attenuated back toward the seaside. With $d_{b} / d=0.7$, the ratio $R$ declined from $59 \%$ to $42.6 \%$ when $\mathrm{K}$ values rose from 10 to $25 \mathrm{~m}$ /day with $\tan \beta$ equals 0.02 ; $\mathrm{R}$ declined to a greater extent for $\tan \beta$ of 0.0 and -0.02 (from $54 \%$ to $41.4 \%$ and from $46.5 \%$ to $27 \%$, respectively), as shown in Figure 8a. In addition, the repulsion ratio $\mathrm{R}$ was just under $10 \%$ for the three bed slopes when hydraulic conductivities ranged from 10 to $25 \mathrm{~m} /$ day and when $\mathrm{d}_{\mathrm{b}} / \mathrm{d}$ ranged from 0.2 to 0.4 . 


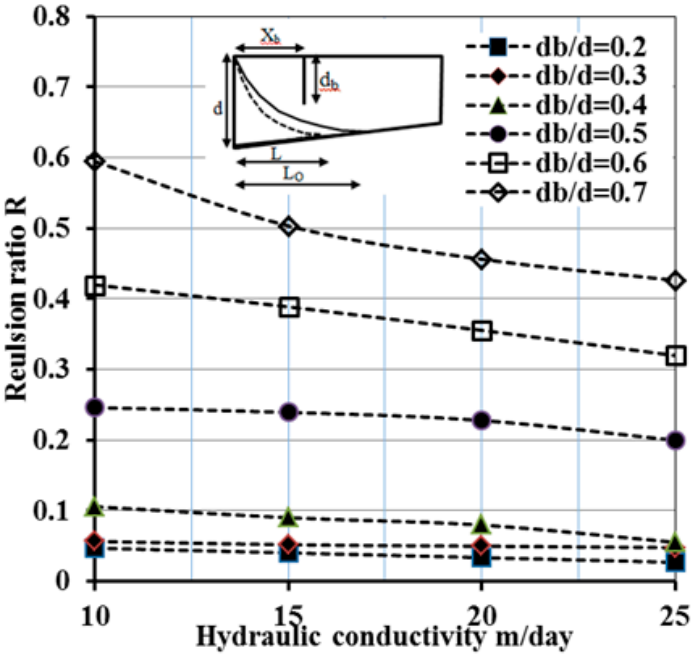

(a)

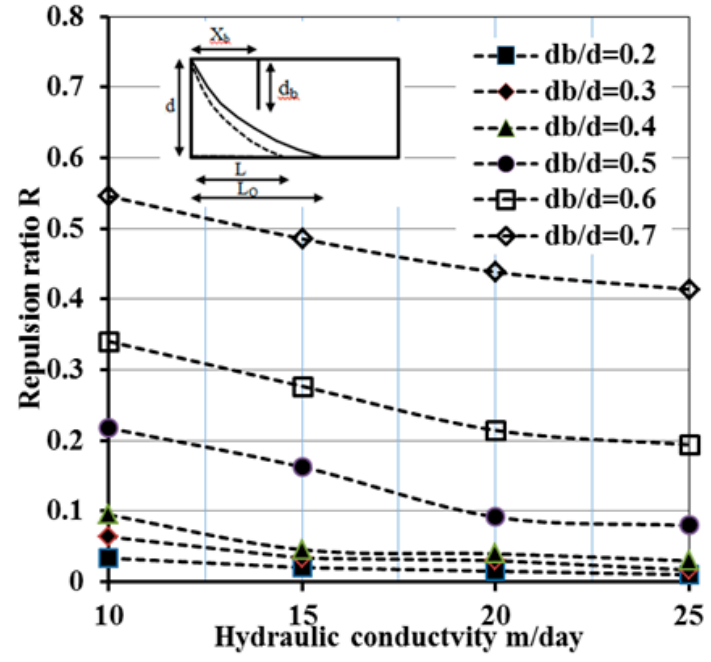

(b)

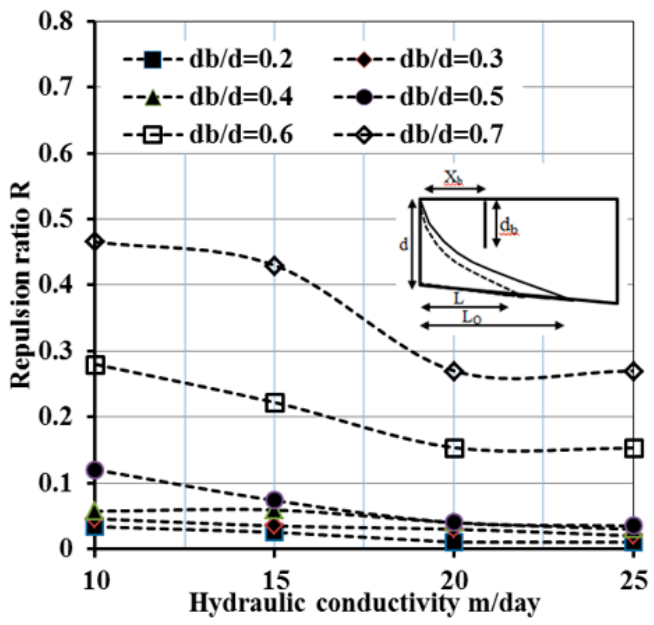

(c)

Figure 8. Relationship between hydraulic conductivity and R for different bed slopes $\tan \beta$ : (a) 0.02 , (b) 0.0 , and (c) -0.02 .

\subsubsection{The Effect of the Hydraulic Gradient (i) on the (R) Ratio in Sloping Unconfined Aquifers}

The effectiveness of the hydraulic gradient (i) on $\mathrm{R}$ was evaluated for four hydraulic gradient values $(0.0015,0.002,0.0025$ and 0.003$)$, with fixed values of $K=10 \mathrm{~m} /$ day, $\rho_{\mathrm{s}}=1025 \mathrm{~kg} / \mathrm{m}^{3}, \mathrm{C}_{\mathrm{s}}=35,000 \mathrm{mg} / \mathrm{L}$, and $X_{b} / L_{o}=0.2$ and for six barrier wall depth ratios $d_{b} / d=0.2,0.3,0.4,0.5,0.6$ and 0.7 (Figure 9) according to three different bed slope values. Increasing the value of $i$ caused the seawater interface to retreat back to the seawater side and increased $R$ values. The $R$ obtained in the case of positive slopes was higher compared with those obtained for horizontal and negative slopes, as shown in Figure 9a,c. Increasing $d_{b} / d$, combined with increasing the i value, caused the SWI interface to move further back to the saltwater part. Rising i from 0.0015 to 0.003 increased R from $58.7 \%$ to $73.3 \%$ when $\tan \beta$ was equal to 0.02 (Figure 9a), while R increased from $54.2 \%$ to $69 \%$ and from $46.1 \%$ to $71.3 \%$ when $\tan \beta$ was equal to 0.0 and -0.02 , respectively (Figure $9 b, c)$. Furthermore, the achieved value of $R$ remained below $25 \%$ with small $\mathrm{d}_{\mathrm{b}} / \mathrm{d}$ values that ranged from 0.2 to 0.4 in the three studied cases of bed slopes. 


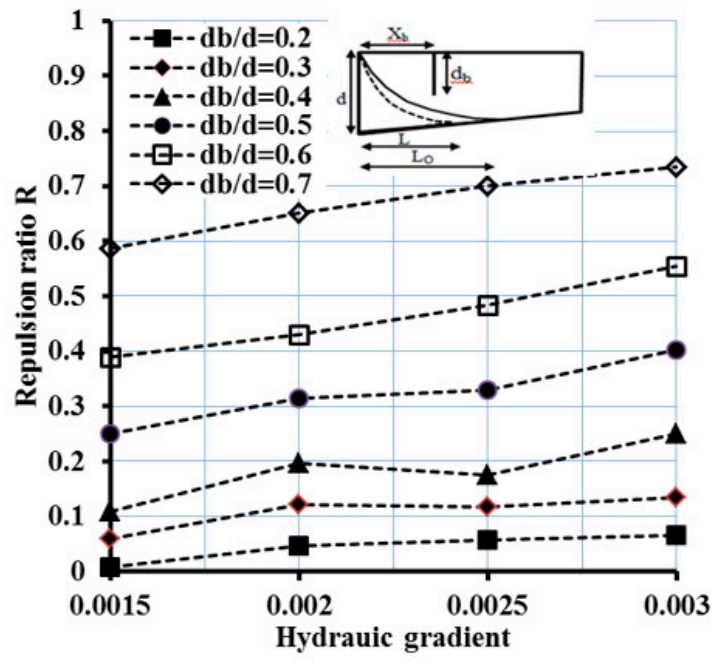

(a)

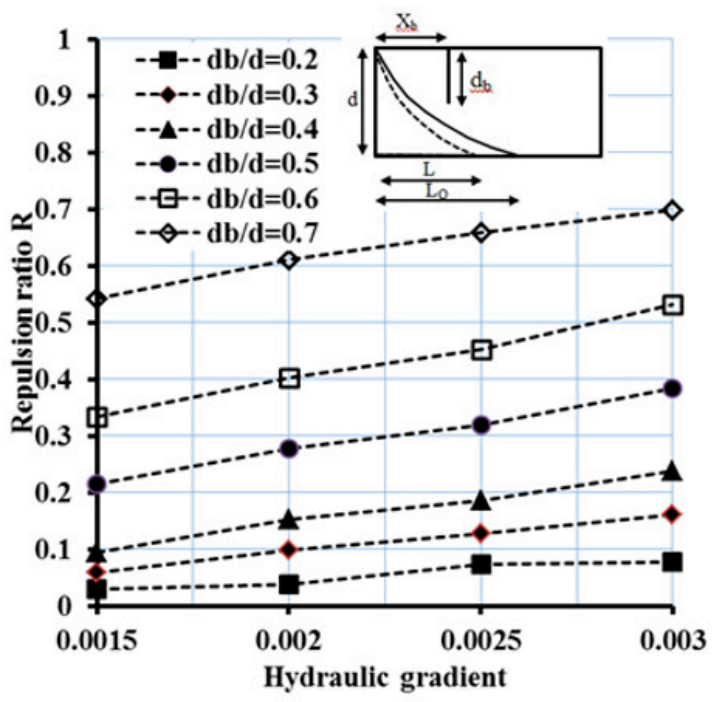

(b)

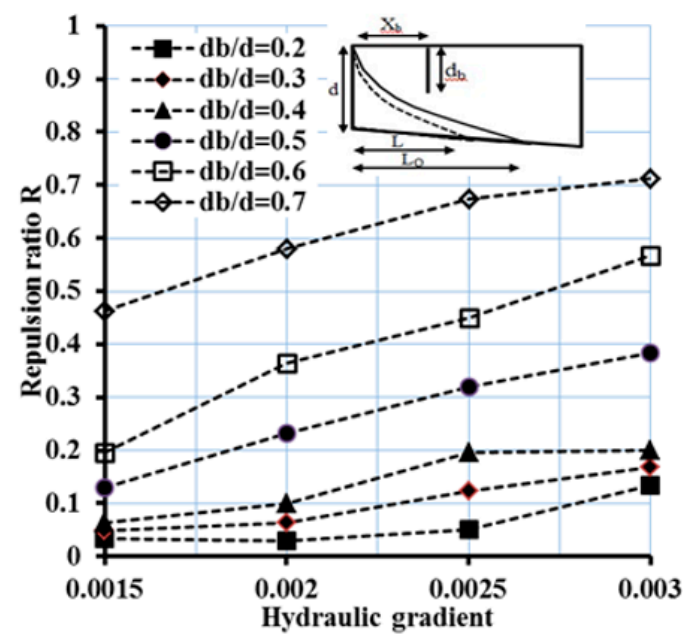

(c)

Figure 9. Relationship between the hydraulic gradient and R for different bed slopes $\tan \beta$ : (a) 0.02 ,

(b) 0.0 , and (c) -0.02 .

\subsubsection{The Effect of Saltwater Density on the (R) Ratio in Sloping Unconfined Aquifers}

The impact of $\rho_{\mathrm{s}}$ on $\mathrm{R}$ was explored for four values of seawater density. This was performed for different six barrier wall depth ratios $\left(\mathrm{d}_{\mathrm{b}} / \mathrm{d}\right)$, with fixed values of the barrier wall location ratio $\mathrm{X}_{\mathrm{b}} / \mathrm{L}_{\mathrm{o}}=0.5, \mathrm{~K}=10 \mathrm{~m} /$ day, and $\mathrm{i}=0.0025$ for three different bed slope values, as shown in Figure 10. Increasing the value of seawater density led to an increase in SWI and a decrease in the repulsion ratio $R$. The achieved $R$ was quite similar for different values of the bed slope, while the lowest $R$ was obtained for the negative bed slope (Figure 10c). Moreover, the ratio $\mathrm{R}$ decreased from $36.7 \%$ to $24.4 \%$ with $d_{b} / d=0.7$ when $\rho_{\mathrm{s}}$ increased from 1022 to $1030 \mathrm{~kg} / \mathrm{m}^{3}$ with $\tan \beta=0.02$ (Figure 10a), and $\mathrm{R}$ decreased from $36.6 \%$ to $20 \%$ and from $23.6 \%$ to $0.0 \%$ in the case of $\tan \beta$ equal to 0.0 and -0.02 , respectively (Figure 10b,c). Low values of $d_{b} / d$ from 0.2 to 0.5 resulted in an R of less than $20 \%$ in the three cases of bed slopes. 


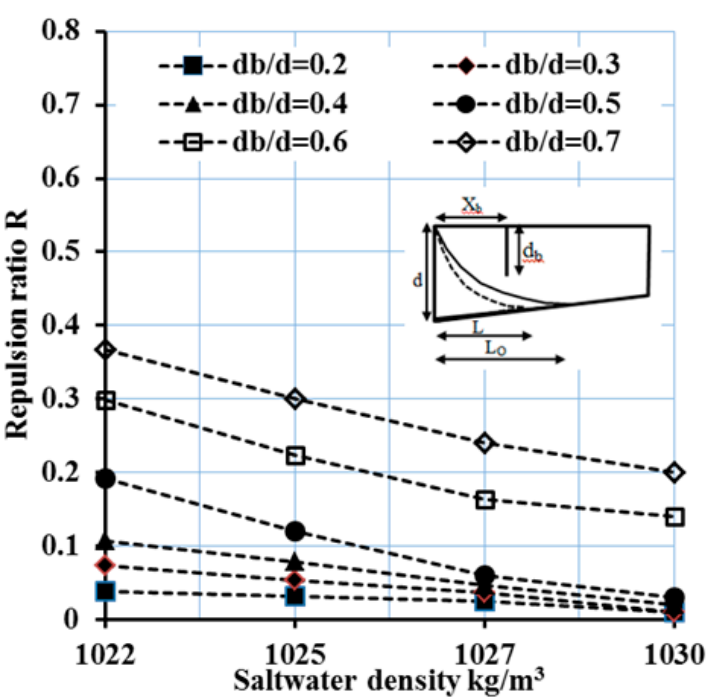

(a)

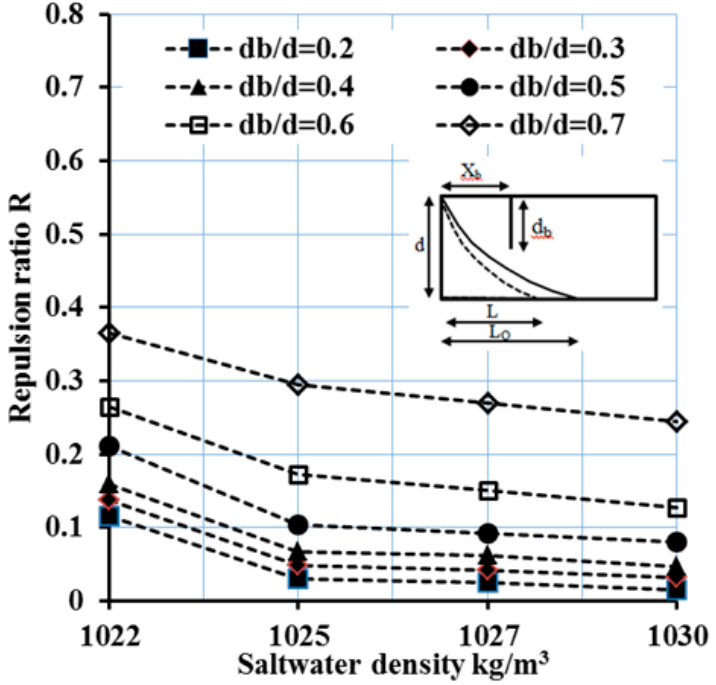

(b)

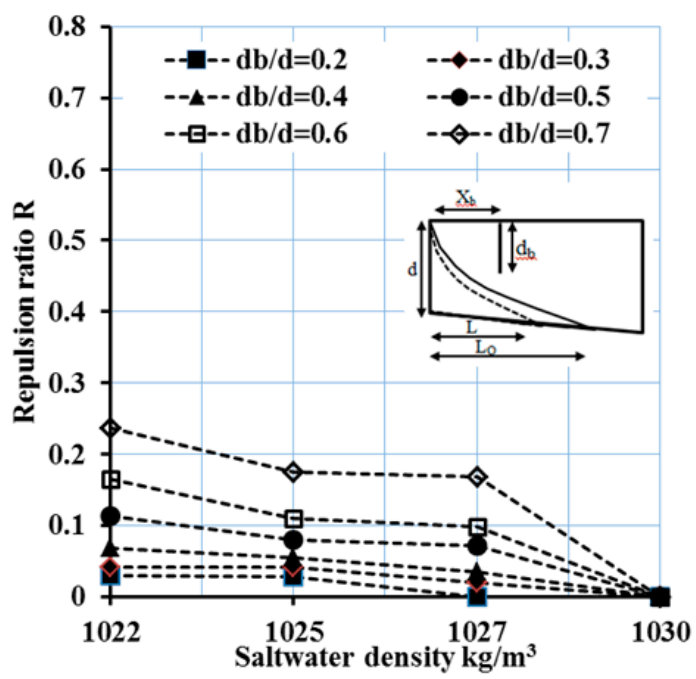

(c)

Figure 10. Relationship between saltwater density and R for different bed slopes $\tan \beta$ : (a) 0.02 , (b) 0.0 , and $(\mathbf{c})-0.02$.

\subsubsection{The Impact of the Bed Slope on the (R) Ratio in Sloping Unconfined Aquifers}

The impact of the bed slope $\tan \beta$ on the $\mathrm{R}$ values was performed for five various bed slope values $(-0.02 \%,-0.01 \%, 0.0 \%, 0.01 \%$ and $0.02 \%)$ with six wall depth ratios $\left(\mathrm{d}_{\mathrm{b}} / \mathrm{d}=0.20,0.30,0.40,0.50,0.60\right.$ and 0.70). This was tested for two barrier wall distance ratios $\left(X_{b} / L_{o}=0.20\right.$ and 0.40$)$ with fixed values of $\mathrm{K}=10 \mathrm{~m} /$ day, $\rho_{\mathrm{s}}=1025 \mathrm{~kg} / \mathrm{m}^{3}, \mathrm{C}_{\mathrm{s}}=35,000 \mathrm{mg} / \mathrm{L}$, and $\mathrm{i}=0.0015$ (Figure 11). Increasing the value of the bed slope decreased the SWI advancement and increased the $\mathrm{R}$ values. Regarding different values of $X_{b} / L_{o}$, embedding the wall near the saline water part with $X_{b} / L_{o}=0.2$ achieved a higher $R$ compared that obtained with $X_{b} / L_{o}=0.40$. In addition, increasing the bed slope from -0.02 to 0.02 with $d_{b} / d$ equal to 0.70 caused $R$ to increase from $3.5 \%$ to $59 \%$ and from $20.8 \%$ to $42 \%$ for $X_{b} / L_{o}$ equal 0.2 and 0.4 , respectively, as shown in Figure 11. A decrease in the depth of the barrier wall $d_{b} / d$ from 0.2 to 0.4 resulted in values of $\mathrm{R}$ that were less than $15 \%$ for different values of $\tan \beta$ (from -0.02 to 0.02 ).

The results of this study confirm that the embedment of the barrier wall deeply into the horizontal aquifer and close to the coastal shore line can achieve about $60 \%$ of repulsion of SWI, this confirms the outcomes from Luyun et al. [28] and Armanuos et al. [32]. Also, the results of the horizontal 
aquifer confirms that embedment of the cutoff wall with a depth of more than half of the aquifer depth has a great impact in controlling SWI and reducing the advancement of saline water moving into the freshwater aquifer; this confirms the results of $[28,32]$.

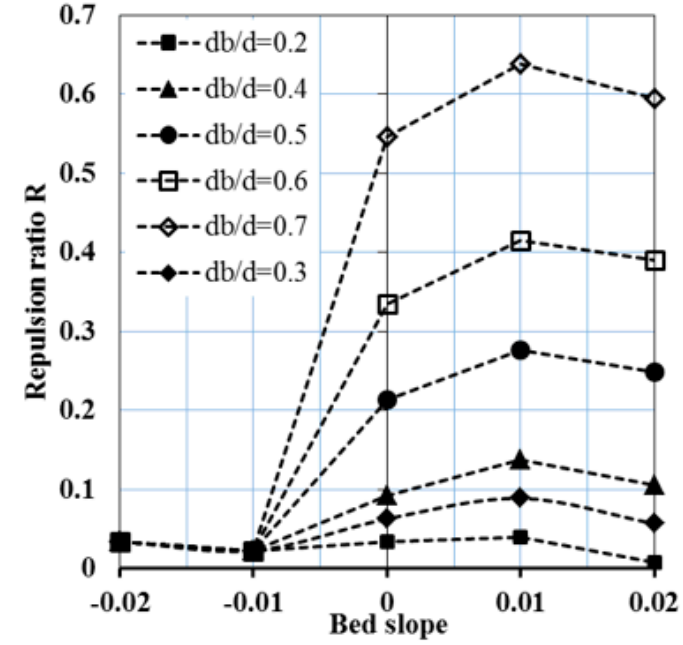

(a)

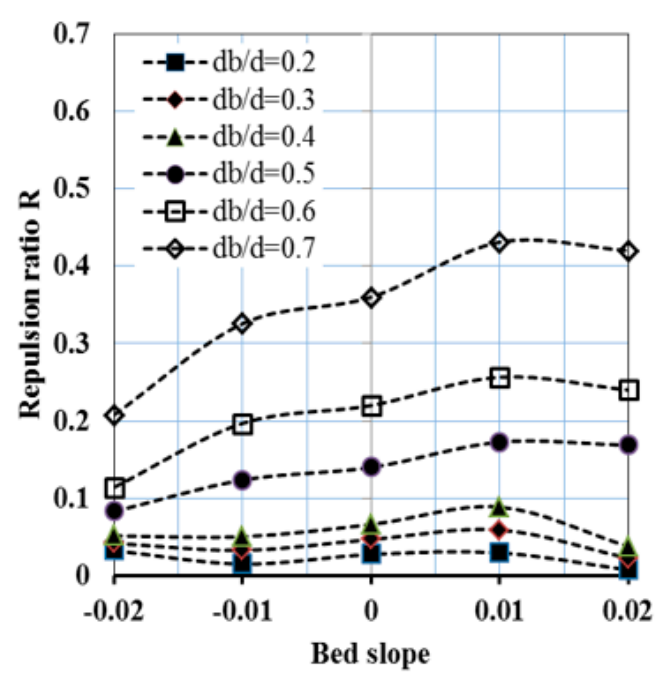

(b)

Figure 11. Relationship between the bed slope and $R$ for barrier wall distance: (a) 0.20 and (b) 0.40 .

The results of sensitivity of parameters for controlling SWI in sloped unconfined aquifers using the flow barrier confirmed that among the checked parameters the depth of barrier wall and the barrier wall locations have a significant impact in controlling SWI. Installing the flow barrier with more depths minimize the movement of saline water to move additional water into the freshwater aquifer. With respect to the tested values of the bed sloping layer, it seems that the barrier wall controls SWI and achieved high $\mathrm{R} \%$ in the case of the positive sloping aquifer, followed by horizontal bed and negative sloping bed. This confirms the point that the slope of the aquifer firstly is a vital parameter on determining the intrusion length in the sloping bed aquifer compared with the horizontal one. The results also confirm that the variations of density of saline water have a significant impact on both intrusion length and how the barrier wall controls the SWI. The saline water intrudes the aquifer more in the case of the negative sloping bed aquifer than the horizontal and positive sloping aquifers.

The dense saline water moves and intrudes more with negative slope aquifer; here, the saline water moves downward with slope, and the slope values have a crucial effect on results compared with horizontal aquifer as there is no effect on slope and positive slope aquifer where the saline water moves upward on the slope layer. With the high density of saline water and negative sloping aquifer, the barrier wall has a small effect on controlling the SWI, on the other hand its effect on reducing the SWI wedge is greater in the horizontal aquifer than the positive sloping aquifer. With the high depths of the barrier wall and installing closer to the coastal area, SWI can be controlled more and a higher repulsion ratio $\mathrm{R}$ can be achieved with a positive sloping bed rather than a horizontal and negative sloping bed. Changing the hydraulic gradient values increases the flow from the freshwater side and helps more to increase the freshwater volume in the aquifer by forcing the saline water to move back towards the seaside. Regarding the hydraulic gradient values, the achieved $\mathrm{R}$ ratio seems to be similar in the three cases of the sloping bed of the aquifers. In addition, with the high depths of the barrier wall combined with low distance from seaside to barrier wall, $\mathrm{R}$ ration increased more in the case of higher gradient values compared with low gradient. It should be mentioned that the results introduced in this study are related to $2 \mathrm{D}$, and in $3 \mathrm{D}$, the barrier wall should be extended along the coast shoreline. 
It should be considered that in this study the impact of a barrier wall on controlling SWI was investigated in positive and negative sloping bed aquifers compared with a horizontal bed aquifer without including pumping from wells. This study only introduces the protection of groundwater in sloping unconfined coastal aquifers and a highly protective potential was observed in the case of installing the physical barrier with greater depths and closer to the coastal line. It is recommended for future studies to study the impact of an underground barrier wall on the movement of seawater intrusion in sloping unconfined coastal aquifers considering different scenarios with and without groundwater pumping. In the case of the existence of groundwater abstraction, the ability of an underground cutoff wall to control and retreat the saltwater intrusion wedge could depend on the number of groundwater wells, distances between wells, abstraction rates, and well locations. Impact of underground cutoff walls for mitigation of SWI in sloped unconfined aquifers could be considered for future studies for low and highly anisotropic groundwater systems.

\subsection{Case Study: The Akrotiri Coastal Aquifer, Cyprus}

The SWI interface in the Akrotiri coastal aquifer, Zakaki area, Cyprus, as well as the application of using an underground barrier wall to control SWI were simulated using the SEAWAT code. The map of the aquifer and the profile concept are presented in Figures A1 and A2 in the Appendix A, respectively [52]. The figures present the conceptual profile of the Akrotiri aquifer. The length and the depth of the aquifer model domain were equal to 3000 and $100 \mathrm{~m}$, respectively. The defined cell dimension is set to $6 \times 6 \mathrm{~m}$ in the X-and Z-directions. The defined seawater head on the seaside was $50 \mathrm{~m}$, the bed slope of the Akrotiri aquifer was about $1.7 \%$, and the recharge rate was $83 \mathrm{~mm} /$ year. The hydraulic aquifer parameters and the inputs of the SEAWAT code are presented in Table 5. The defined hydraulic conductivity is $28 \mathrm{~m} /$ day; the assigned specific yield is 0.2 , and the defined freshwater and seawater densities were 988 and $1024 \mathrm{~kg} / \mathrm{m}^{3}$, accordingly. The SEAWAT was tested for the steady-state condition for a recharge rate of $\mathrm{r}=83 \mathrm{~mm} / \mathrm{year}$, and the assigned flow inland boundary was $314 \mathrm{~m}^{3} /$ year $/ \mathrm{m}$. The length of the SWI wedge in the steady-state using the SEAWAT code was equal to $480 \mathrm{~m}$, compared to $435.9 \mathrm{~m}$ for the sloping aquifer model by [52]. The results of the steady-state SWI in the investigated case study showed a good agreement among the SEAWAT code and the estimated value of the sloping aquifer model by [52]. After the model reached the steady-state condition, the SEAWAT was tested for different cases considering different depths and locations of the barrier wall to control SWI.

Table 5. Parameters of Cyprus aquifer [52] and SEAWAT numerical model inputs.

\begin{tabular}{cc}
\hline Parameter & Value \\
\hline Slope of aquifer bed & $\tan \beta=0.0170025$ \\
Inland inflow boundary & $314 \mathrm{~m}^{3} /$ year $/ \mathrm{m}$ \\
Aquifer hydraulic conductivity & $28 \mathrm{~m} / \mathrm{day}$ \\
Mean specific yield & 0.20 \\
Length of aquifer & $3000 \mathrm{~km}$ \\
depth of aquifer at coast & $50 \mathrm{~m}$ \\
Discharge rate & $0.0 \mathrm{~m}^{3} / \mathrm{year} / \mathrm{m}$ \\
Natural recharge & $83 \mathrm{~mm} / \mathrm{year}$ \\
Sloping SWI toe location $\mathrm{L}_{\mathrm{t}}(\mathrm{m})$ & $435.9 \mathrm{~m}$ \\
Freshwater density & $988.275 \mathrm{~kg} / \mathrm{m}^{3}$ \\
Saltwater density & $1024 \mathrm{~kg} / \mathrm{m}^{3}$ \\
Solute concentration base & $100 \mathrm{mg} / \mathrm{L}$ \\
Concentration of freshwater & $0.0 \mathrm{mg} / \mathrm{L}$ \\
Salt Concentration & $35,000 \mathrm{mg} / \mathrm{L}$ \\
Dispersivity in longitudinal direction & $2 \mathrm{~m}$ \\
Dispersivity in transverse direction & $2 \mathrm{~m}$ \\
Dimension of model cell & $6 \times 6 \mathrm{~m}$ \\
Width of aquifer & $1 \mathrm{~m}$ \\
\hline
\end{tabular}


Figure A3 shows the seawater distribution in the Akrotiri coastal aquifer for the steady-state condition and for the embedment of the barrier wall with a distance ratio $X_{b} / L_{o}=0.4$ and with seven different barrier wall ratios $d_{b} / d=0.2,0.3,0.4,0.5,0.6,0.7$ and 0.8. Embedment of the barrier wall in the Akrotiri coastal aquifer led to the retreat of SWI and a decrease in the length SWI ratio. The R values increased with the deeper embedment of the barrier wall into the Akrotiri coastal aquifer. As the barrier wall was embedded closer to the seawater side, the SWI retreated further and the R ratio of SWI increased. Installing the wall at the distance $X_{b} / L_{o}=0.4$ led to a decrease in the length of the SWI wedge from $480 \mathrm{~m}$ to $474,432,366,324,322$ and $186 \mathrm{~m}$ for depth ratios $\mathrm{d}_{\mathrm{b}} / \mathrm{d}=0.2,0.3,0.4,0.5,0.6,0.7$ and 0.8 , respectively. Figure A4 presents the seawater distribution in the Akrotiri coastal aquifer for the steady-state condition and for an embedded barrier wall with a distance ratio $X_{b} / L_{o}=0.6$ and seven different barrier wall ratios $\left(\mathrm{d}_{\mathrm{b}} / \mathrm{d}=0.2,0.3,0.4,0.5,0.6,0.7\right.$ and 0.8$)$. Embedment of the barrier wall in the Akrotiri coastal aquifer at the distance $\mathrm{X}_{\mathrm{b}} / \mathrm{L}_{\mathrm{o}}=0.6$ led to a decrease in the length of the SWI wedge from $480 \mathrm{~m}$ to $479,468,456,414,384,306$ and $282 \mathrm{~m}$ for depth ratios $\mathrm{d}_{\mathrm{b}} / \mathrm{d}=0.2,0.3,0.4,0.5,0.6$, 0.7 and 0.8 , respectively. Figure A5 shows the saltwater distribution in the Akrotiri aquifer for the steady-state condition and for an embedded barrier wall with depth ratio $\mathrm{d}_{\mathrm{b}} / \mathrm{d}=0.5$ and five different barrier wall distance ratios $\left(X_{b} / L_{o}=1.0,0.8,0.6,0.4\right.$ and 0.2$)$. The saltwater wedge length decreased as the barrier wall was embedded closer to the seaside with a barrier wall length ratio of less than 1.0. Installing the barrier wall at a distance that exceeded the SWI toe had no effect on the retreat of SWI. Embedding the barrier wall with depth $d_{b} / d=0.5$ for distances $X_{b} / L_{o}=1.0,0.8,0.6,0.4$ and 0.2 forced the SWI wedge to retreat to lengths of 474, 444, 414, 366 and $294 \mathrm{~m}$, respectively. Figure 12 shows the saltwater distribution in the Akrotiri aquifer for the steady-state condition and for an embedded barrier wall with depth ratio $d_{b} / d=0.7$ and five different barrier wall distance ratios $\left(X_{b} / L_{o}=1.0,0.8\right.$, 0.6, 0.4 and 0.2). Embedment of the barrier wall with depth $d_{b} / d=0.7$ for distances $X_{b} / L_{o}=1.0,0.8$, $0.6,0.4$ and 0.2 forced the SWI wedge to retreat more compared with $d_{b} / d=0.7$, with the SWI wedge length decreasing to $462,384,306,222$ and $138 \mathrm{~m}$, respectively.

Figure 13a shows the relationship between the repulsion ratios of SWI in the Akrotiri coastal aquifer with different values of $X_{b} / L_{o}$ considering eight different values of $d_{b} / d$. Figure 13a confirms that the embedded barrier wall has an important effect on the control of SWI in the aquifer. With $d_{b} / d$ equal to 0.2 and $X_{b} / L_{o}$ ranging from 0.2 to 1.0 , a low repulsion ratio $R$ was achieved. On the other hand, with a deep barrier wall with $d_{b} / d=0.9$ and $X_{b} / L_{o}=0.2$, the maximum value of $R$ could be achieved. Figure $13 \mathrm{~b}$ presents the relationship between the repulsion ratios of SWI in the Akrotiri coastal aquifer with different depth values $d_{b} / d$ considering five different distance ratios $X_{b} / L_{o}$. Figure $13 a, b$ confirms that installing the barrier wall in the Akrotiri coastal aquifer near the seaside and deep into the aquifer achieved higher repulsion ratio values $R$, forced SWI to attenuate further back toward the seaside, and decreased the length of the SWI wedge. With $\mathrm{d}_{\mathrm{b}} / \mathrm{d}=0.8, \mathrm{R}$ decreased from $81.25 \%$ to $3.75 \%$, and when the barrier wall distance ratio increased from 0.2 to 1.0 , these values decreased from $38.75 \%$ to $1.25 \%$ in the case of $d_{b} / d=0.5$. In addition, embedding the barrier wall with a ratio ranging from 0.2 to 0.4 achieved an R of below $20 \%$ in all barrier wall locations. Figure $13 \mathrm{c}$ presents the relationship between the SWI length ratio in the Akrotiri aquifer with different depths $\mathrm{d}_{b} / \mathrm{d}$ and different distances $X_{b} / L_{0}$. The SWI length ratio $L / L_{a}$ decreased as the barrier wall was installed further into the aquifer. On the other hand, embedding the barrier wall with low depths $d_{b} / d$ and farther from the seaside had no effect on the control and mitigation of SWI in the Akrotiri aquifer. With $d_{b} / d=0.6$, the SWI length ratio increased from $24.6 \%$ to $47.7 \%$ when the barrier wall distance ratio increased from 0.2 to 1.0. The results confirm that barrier wall control SWI in the Akrotiri aquifer, as the aquifer is considered a positive sloping bed aquifer with $1.7 \%$ slope, embedment of barrier wall close the Mediterranean coast $\left(\mathrm{X}_{\mathrm{b}} / \mathrm{L}_{\mathrm{o}}=0.2\right.$ to 0.4$)$ with depth more than $0.5 \mathrm{~d}$ achieved repulsion of more than $50 \%$ of SWI in the Akrotiri aquifer. With $d_{b} / d=0.8$ and $X_{b} / L_{o}=0.2$, a highest value of $R$ of SWI about $81.25 \%$ can be achieved, as presented in Figures 12 and 13. 


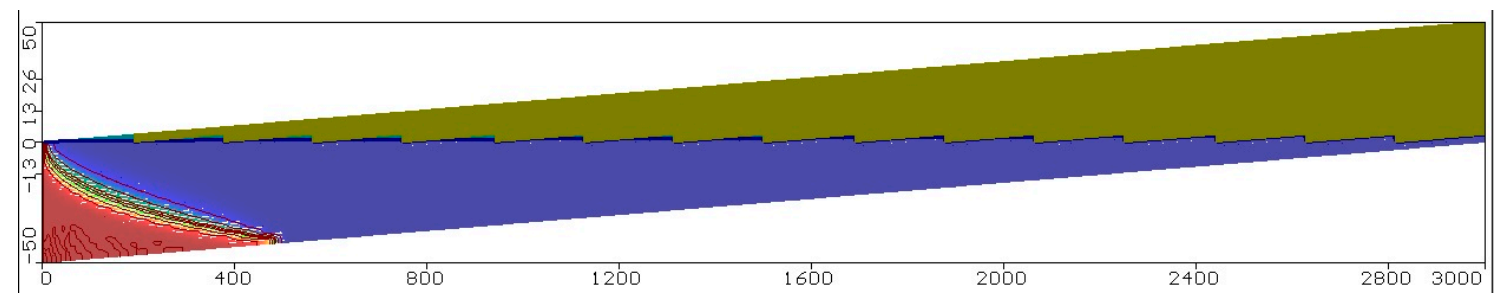

(a)

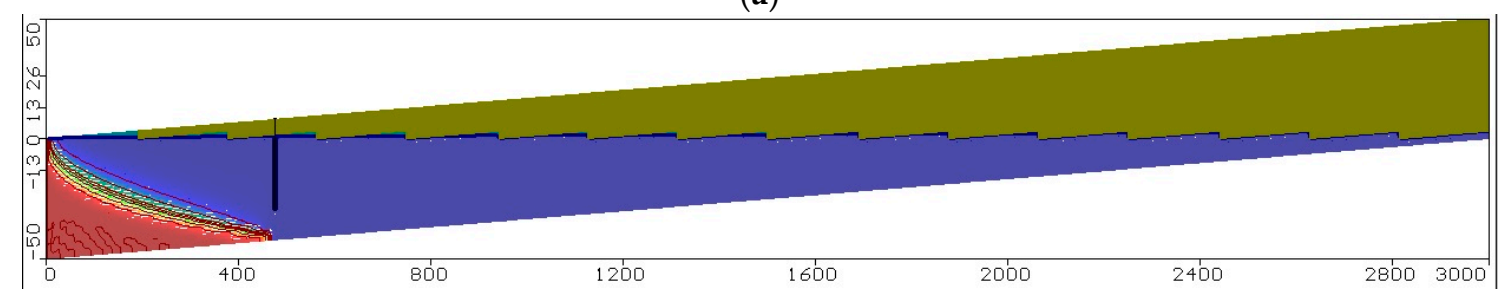

(b)

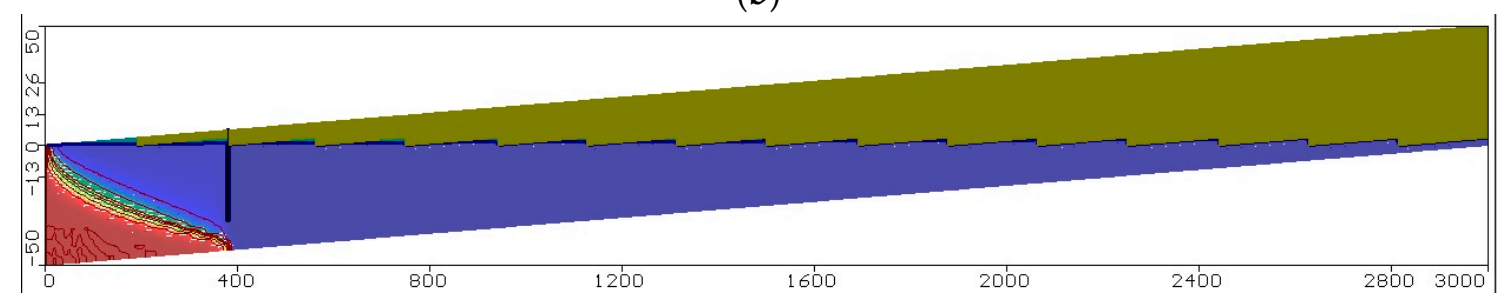

(c)

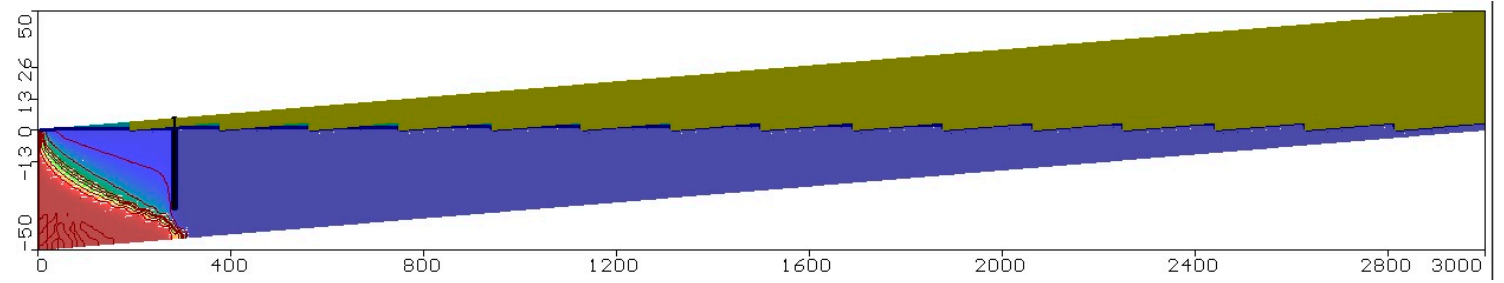

(d)

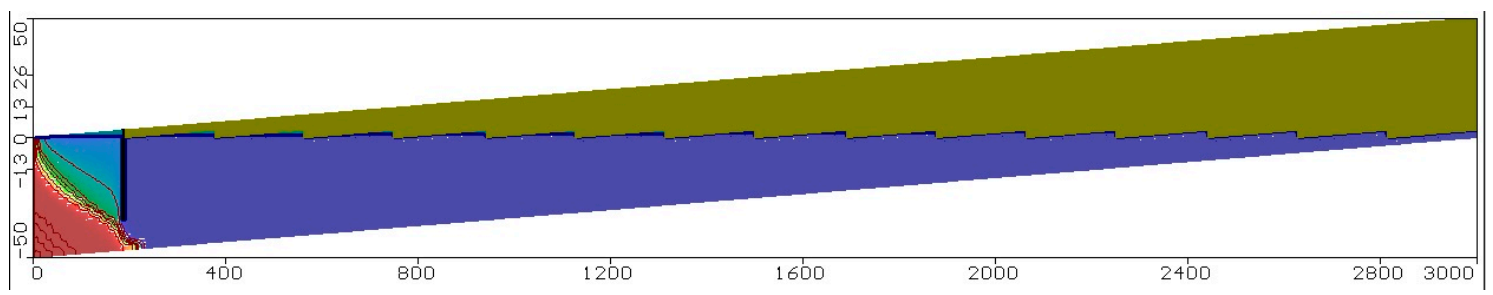

(e)

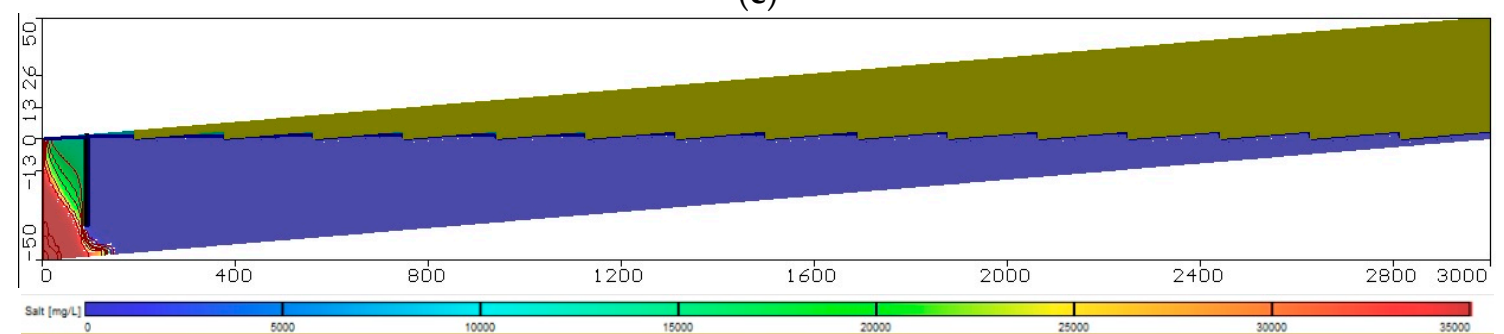

(f)

Figure 12. Saltwater distribution (in $\mathrm{mg} / \mathrm{L}$ ) in the Akrotiri aquifer for (a) the steady state and embedded barrier wall with $\mathrm{d}_{\mathrm{b}} / \mathrm{d}=0.7$ and (b) $\mathrm{X}_{\mathrm{b}} / \mathrm{L}_{\mathrm{o}}=1.0$, (c) $\mathrm{X}_{\mathrm{b}} / \mathrm{L}_{\mathrm{o}}=0.8,(\mathbf{d}) \mathrm{X}_{\mathrm{b}} / \mathrm{L}_{\mathrm{o}}=0.6,(\mathbf{e}) \mathrm{X}_{\mathrm{b}} / \mathrm{L}_{\mathrm{o}}=0.4$ and (f) $\mathrm{X}_{\mathrm{b}} / \mathrm{L}_{\mathrm{o}}=0.2$. 


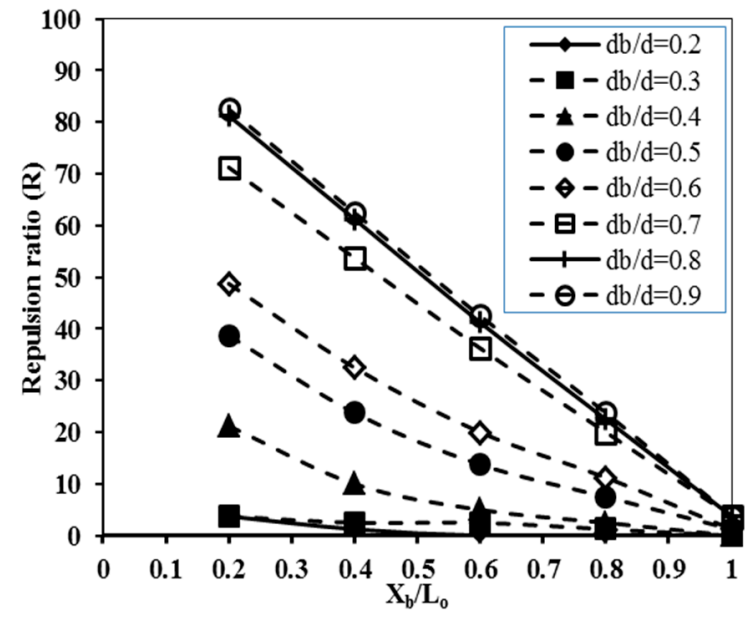

(a)

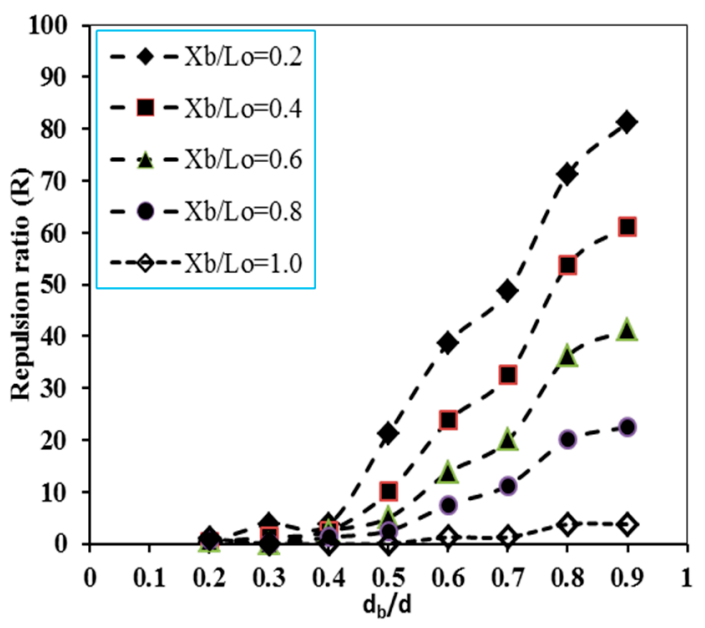

(b)

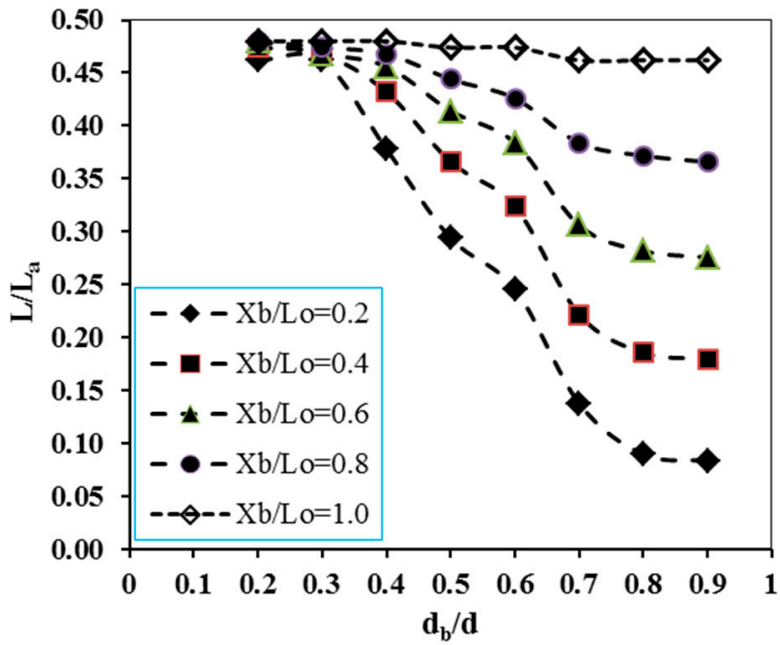

(c)

Figure 13. Relationship between the repulsion ratios of SWI in the Akrotiri aquifer with different values of (a) $X_{b} / L_{o}$, (b) $d_{b} / d$, and (c) relationship between the SWI length ratio with different $d_{b} / d$ and $X_{b} / L_{o}$.

\section{Conclusions}

Groundwater contamination by saltwater intrusion is very common in the coastal aquifers. The human activities and the increasing of groundwater abstraction from coastal aquifers accelerates the degree of saline water pollution. Seawater intrusion causes deterioration of water quality and quantity in coastal aquifer systems. SEAWAT was implemented to investigate the effect of using barrier walls to control SWI in sloped unconfined aquifers. Three cases of bed slopes, namely, positive, horizontal, and negative slopes, were tested. The impact of changing the hydraulic parameters of the aquifer on the length of the SWI wedge was tested by varying the bed slope, hydraulic gradient, hydraulic conductivity, and saltwater density. Secondly, the impact of changing the same parameters on the $\mathrm{R}$ ratio of saltwater was tested, in addition to the depth of the barrier wall ratio and the barrier wall distance ratio. The SEAWAT numerical model results of the saltwater intrusion wedge were compared with the results of the analytical solution to validate the model. The ratio of $\mathrm{R}$ increased from $0.30 \%$ to $59 \%$ as $d_{b} / d$ increased from 0.2 to 0.7 for the unconfined aquifer with a positive bed slope. On the other hand, lower values of $\mathrm{R}$ were achieved for negative and horizontal bed slopes, with $\mathrm{R}$ increasing from $1.8 \%$ to $41.7 \%$ and from $3.4 \%$ to $46.9 \%$, respectively, compared with values obtained for positive ones. With respect to the bed slope of the unconfined aquifer, embedding the barrier wall through the aquifer with a negative bed slope achieved a higher $\mathrm{R}$ ratio of SWI than that achieved with 
horizontal and positive bed slopes. On the other hand, embedding the barrier wall near the seawater side in the unconfined aquifer with a negative bed slope forced the saltwater wedge to attenuate further back compared with the results obtained for positive and horizontal slopes. The maximum repulsion ratio $\mathrm{R}$ was achieved when the barrier wall was embedded near the seawater side. $\mathrm{R}$ values decreased from $68.75 \%$ to $7.21 \%$ when $X_{b} / L_{o}$ increased from 0.2 to 1.0 in the case of the aquifer with a negative bed slope. On the other hand, R decreased from $67.0 \%$ to $5.3 \%$ and from $64 \%$ to $5.1 \%$ in the case of horizontal and positive slopes, respectively. Increasing the hydraulic gradient caused $\mathrm{R}$ values to increase. Increasing the saltwater density accelerated the advancement of saltwater inland into the aquifer and embedding the barrier wall $\left(\mathrm{d}_{\mathrm{b}} / \mathrm{d}=0.7\right)$ was required to achieve an $\mathrm{R}$ value of $20 \%$. The SWI wedge length increased with the increase in the hydraulic conductivity value when the barrier wall was used to control SWI, and the retreat of the SWI wedge was greater for positive and horizontal slopes than that for the negative slope. Application of the barrier wall to control the SWI in the Akrotiri coastal aquifer confirmed that embedment of the barrier wall with $\mathrm{d}_{\mathrm{b}} / \mathrm{d}=0.7$ and 0.8 forced the SWI to retreat and achieved maximum $\mathrm{R}$ values of $71.25 \%$ and $81.25 \%$, respectively, with the length of the SWI wedge decreasing to 138 and $90 \mathrm{~m}$, respectively. It is recommended that cost-benefit analysis be integrated with numerical analysis to determine the optimum depths of the barrier wall $\left(d_{b} / d\right)$ and its locations $\left(\mathrm{X}_{\mathrm{b}} / \mathrm{L}_{\mathrm{O}}\right)$ to control SWI in sloped unconfined aquifers. Using the barrier wall as a countermeasure has a substantial impact on the control of SWI in sloped unconfined coastal aquifers. The outcomes of this study can be considered by decision makers for management and controlling of saltwater intrusion as a kind of groundwater contamination in coastal aquifers. It is recommended for future research to investigate the impact of an underground barrier wall on the movement of SWI in sloping unconfined coastal aquifers considering different scenarios with and without groundwater pumping.

Author Contributions: Conceptualization, A.M.A., N.A.-A. and Z.M.Y.; data curation, A.M.A.; formal analysis, A.M.A. and N.A.-A.; investigation, A.M.A., N.A.-A. and Z.M.Y.; methodology, A.M.A.; project administration, Z.M.Y.; software, A.M.A.; supervision, N.A.-A. and Z.M.Y.; validation, A.M.A., N.A.-A. and Z.M.Y.; visualization, N.A.-A. and Z.M.Y.; writing-original draft, A.M.A., N.A.-A. and Z.M.Y.; writing-review and editing, N.A.-A. and Z.M.Y. All authors have read and agreed to the published version of the manuscript.

Funding: This research received no external funding.

Conflicts of Interest: The authors declare no conflict of interest.

\section{Appendix A}

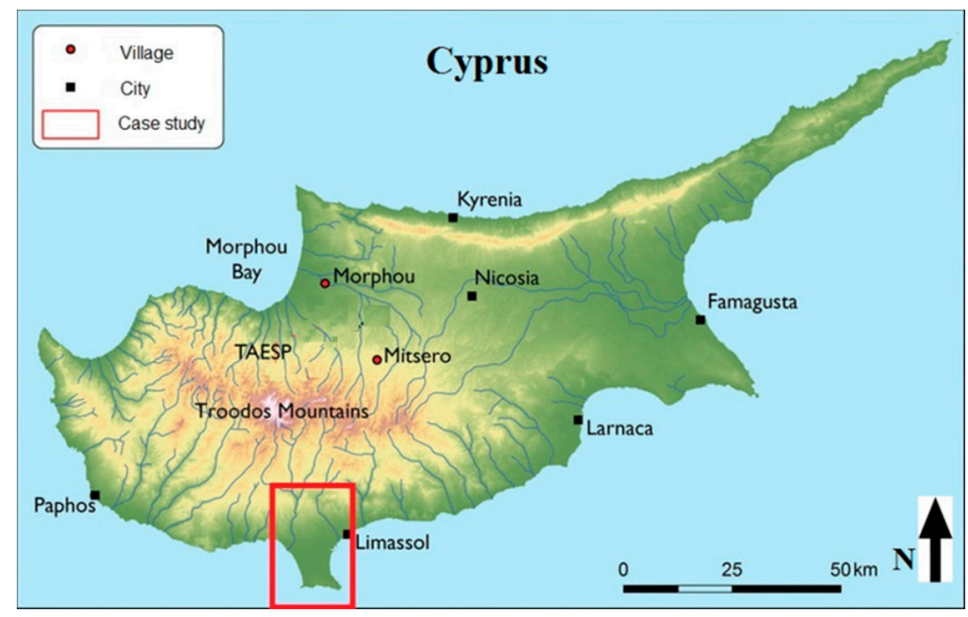

Figure A1. Cont. 


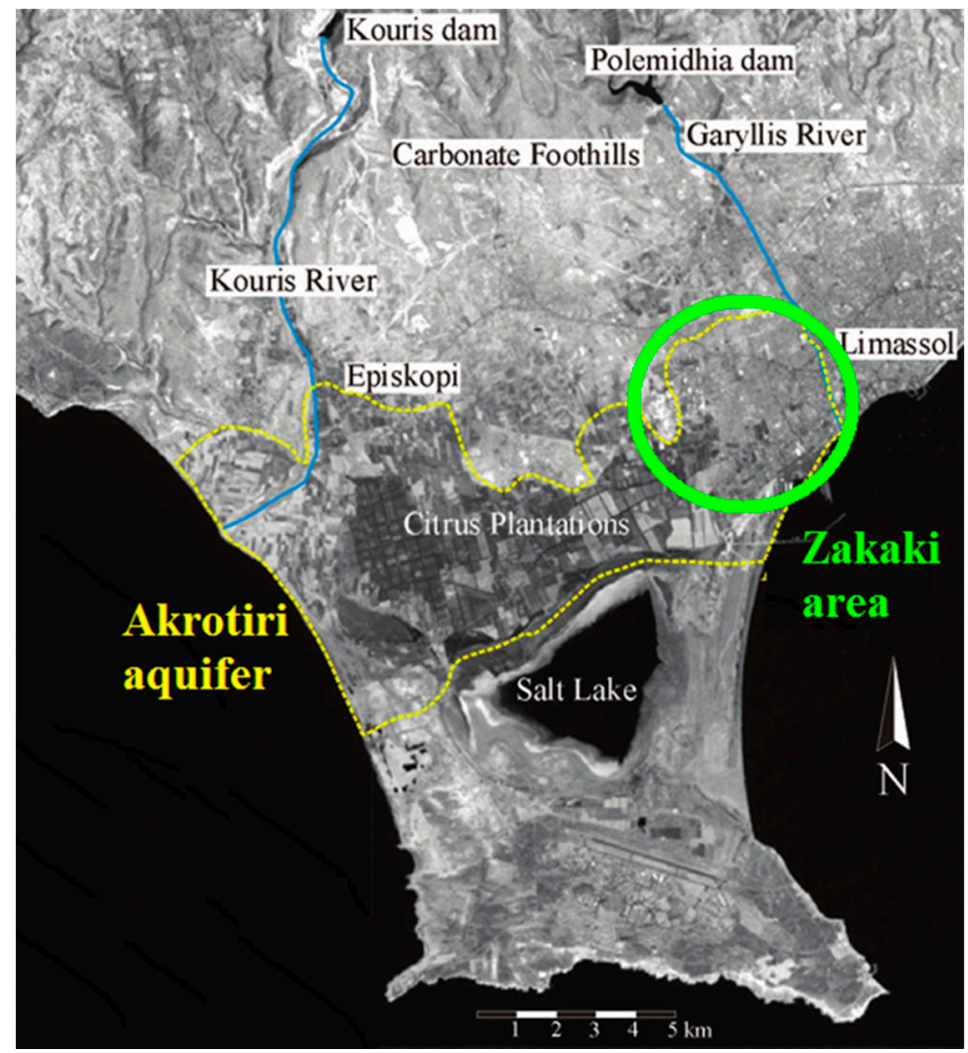

Figure A1. Map of the Akrotiri coastal aquifer, Zakaki area, Cyprus [52].

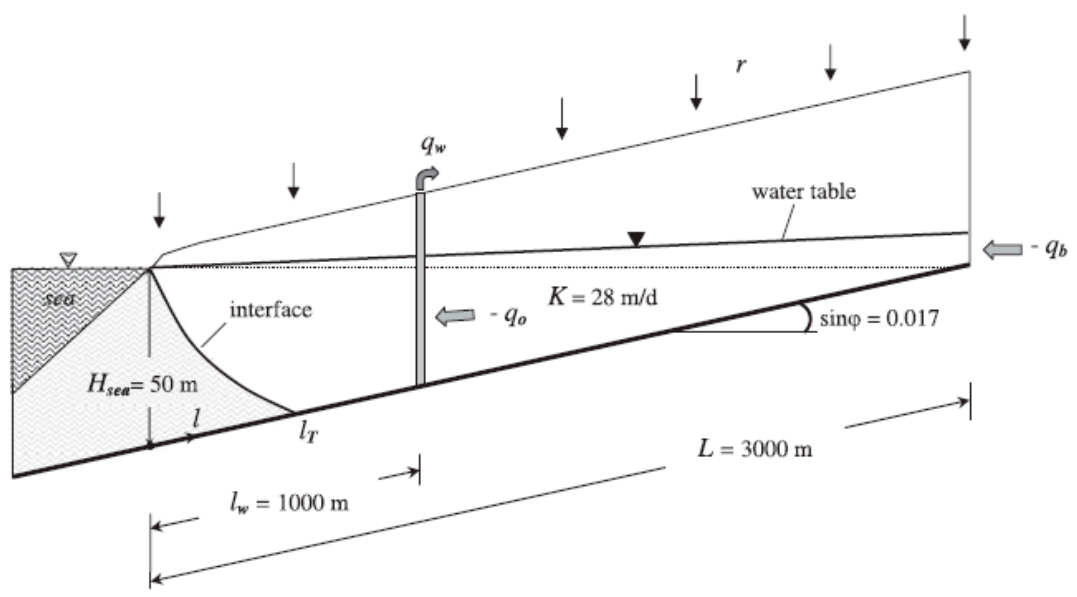

Figure A2. Profile concept of the Akrotiri aquifer, Zakaki area [52].

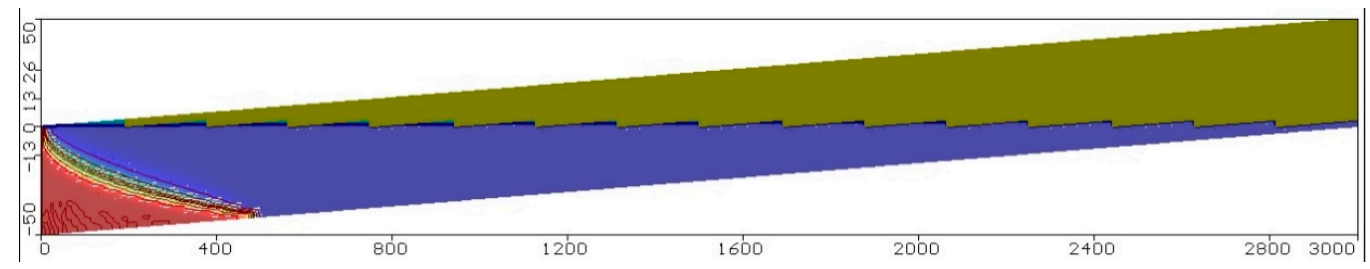

(a)

Figure A3. Cont. 


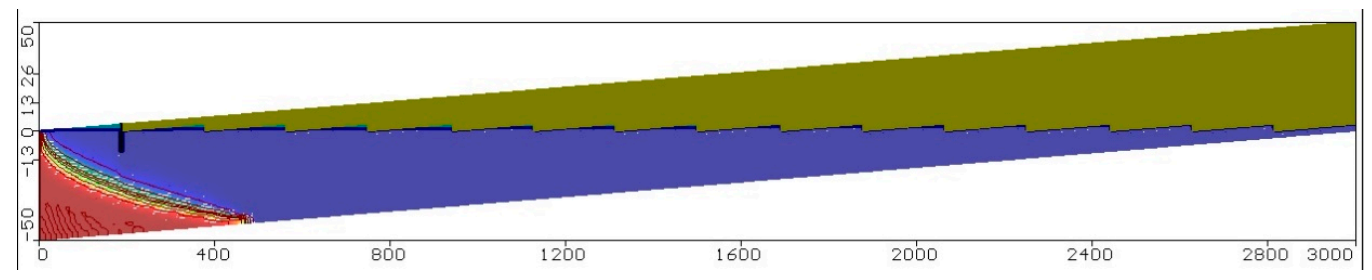

(b)

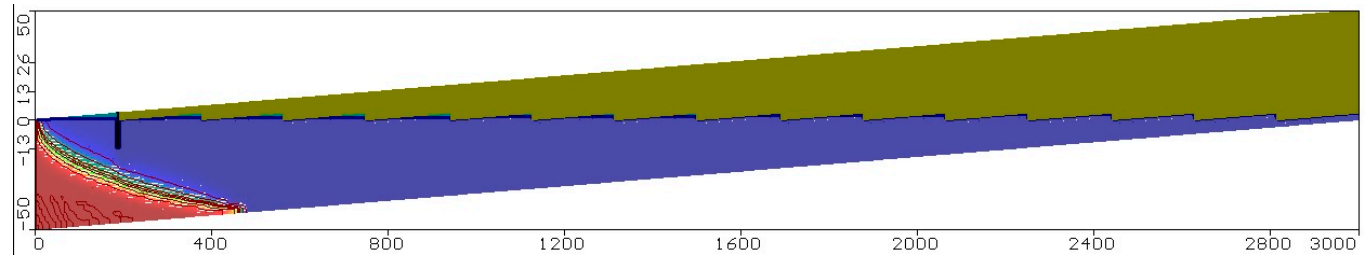

(c)

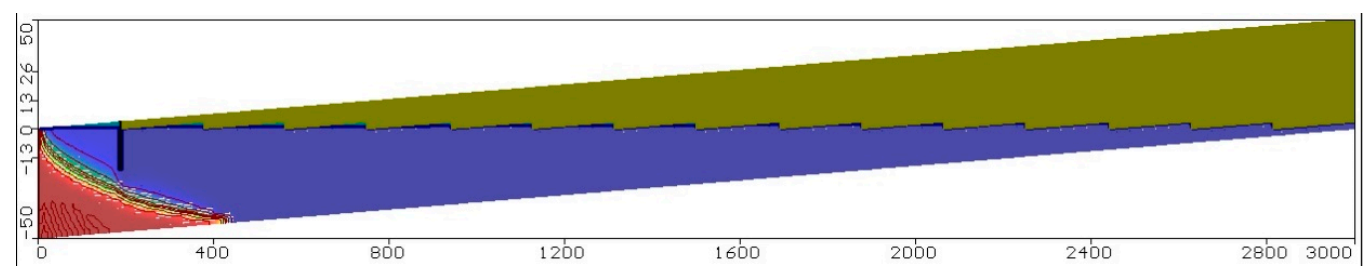

(d)

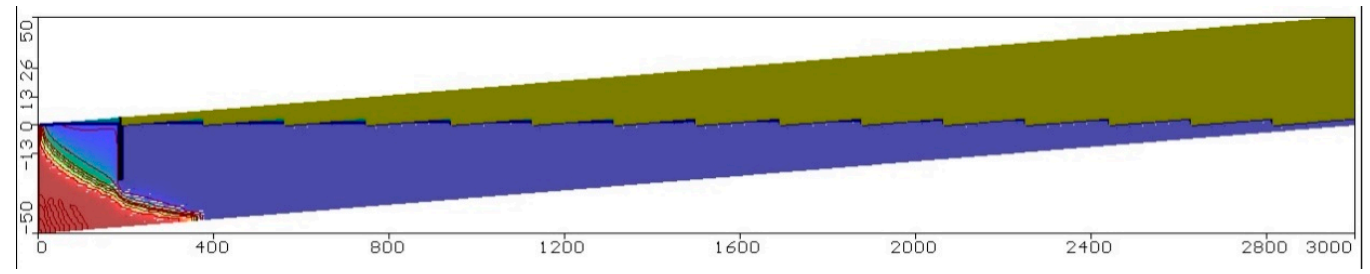

(e)

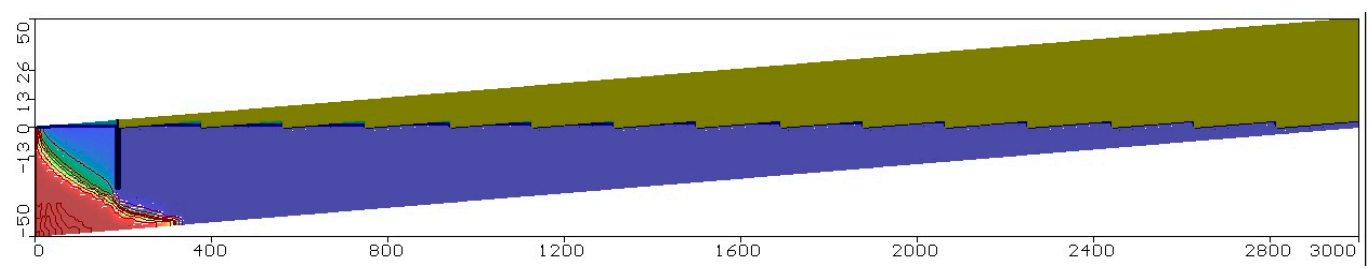

(f)

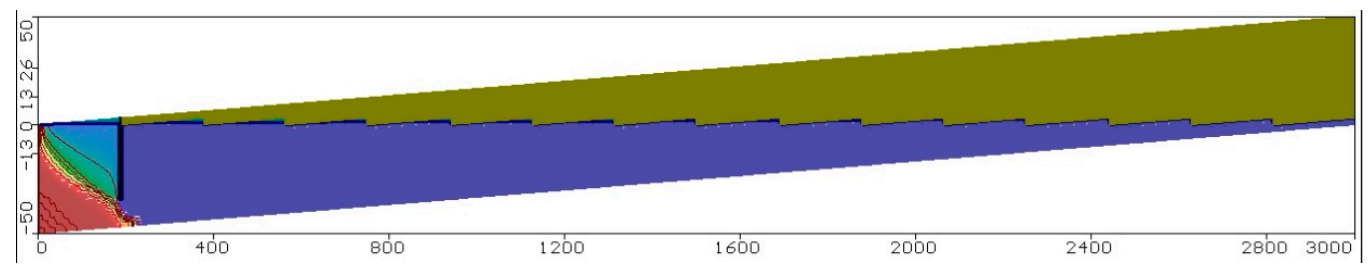

(g)

Figure A3. Cont. 


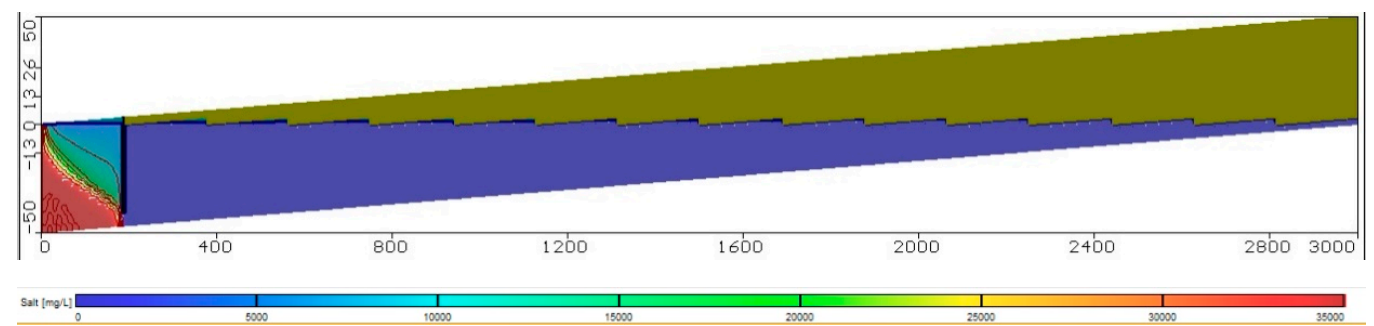

(h)

Figure A3. Saltwater distribution (in $\mathrm{mg} / \mathrm{L}$ ) in the Akrotiri aquifer for (a) the steady state and embedded barrier wall with $X_{b} / L_{o}=0.4$ and $(\mathbf{b}) \mathrm{d}_{\mathrm{b}} / \mathrm{d}=0.2,(\mathbf{c}) \mathrm{d}_{\mathrm{b}} / \mathrm{d}=0.3,(\mathbf{d}) \mathrm{d}_{\mathrm{b}} / \mathrm{d}=0.4,(\mathbf{e}) \mathrm{d}_{\mathrm{b}} / \mathrm{d}=0.5,(\mathbf{f}) \mathrm{d}_{\mathrm{b}} / \mathrm{d}=0.6$, (g) $d_{b} / d=0.7$ and $(\mathbf{h}) d_{b} / d=0.8$

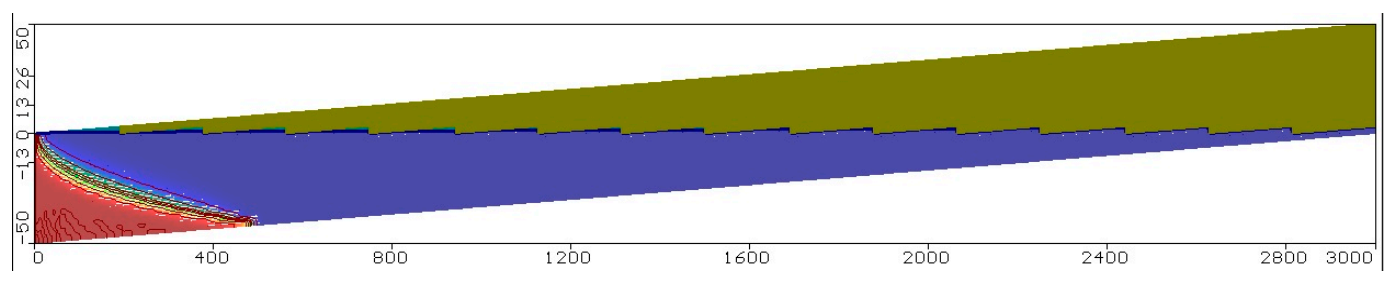

(a)

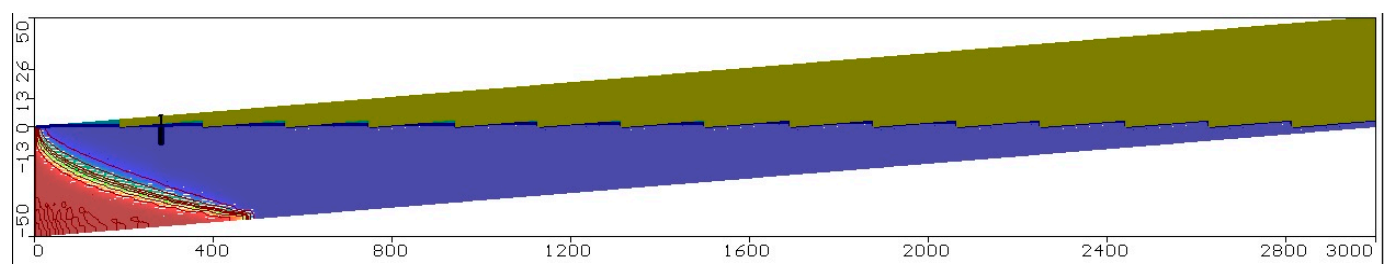

(b)

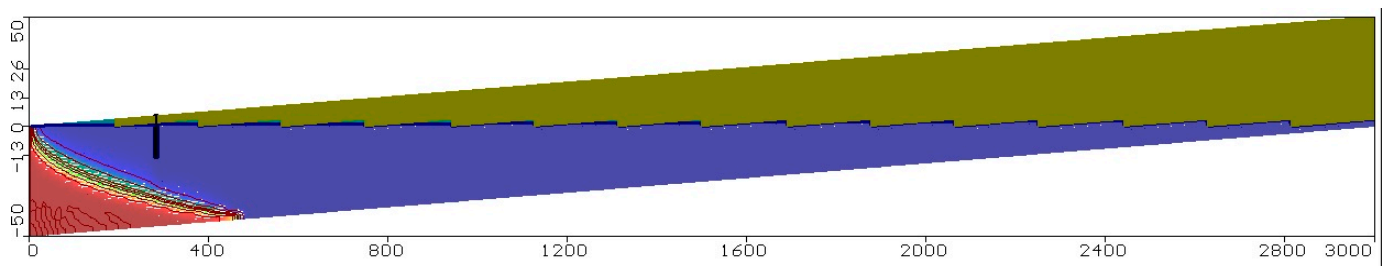

(c)

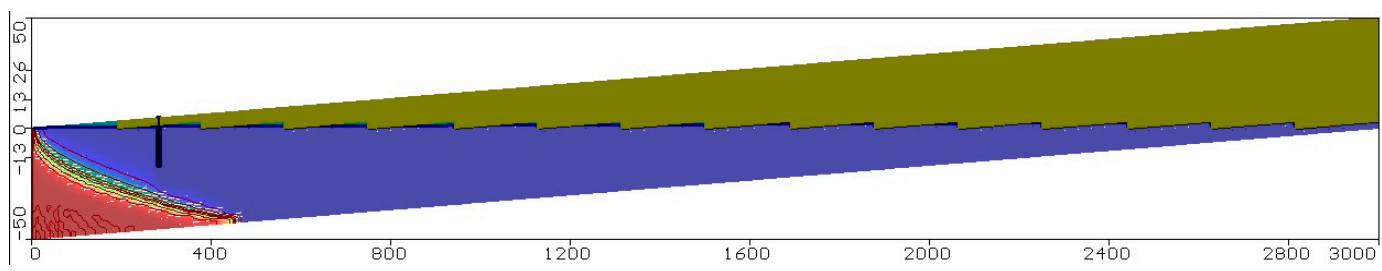

(d)

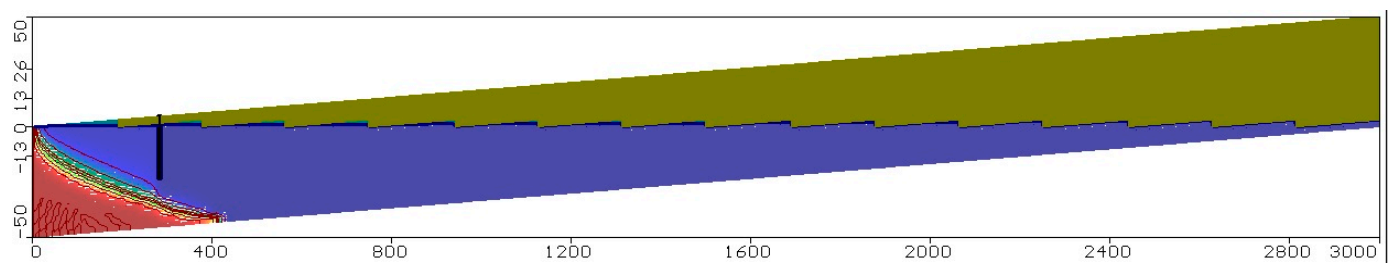

(e)

Figure A4. Cont. 


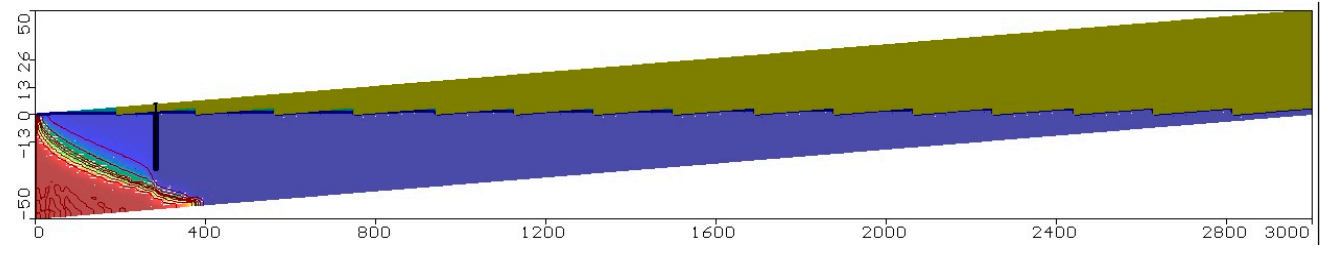

(f)

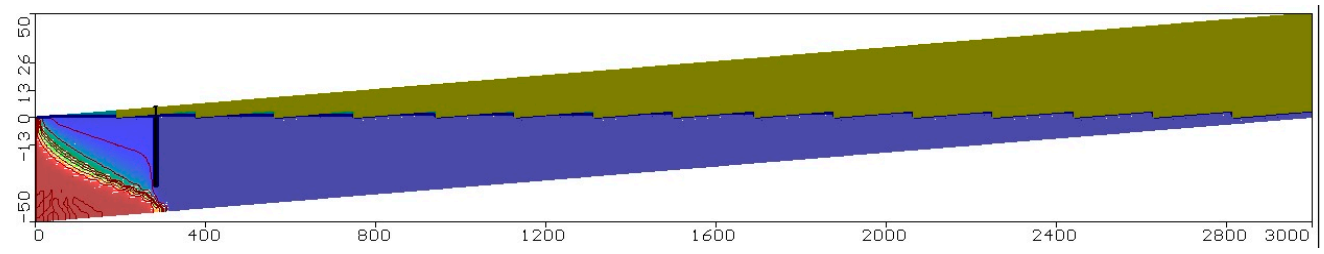

(g)

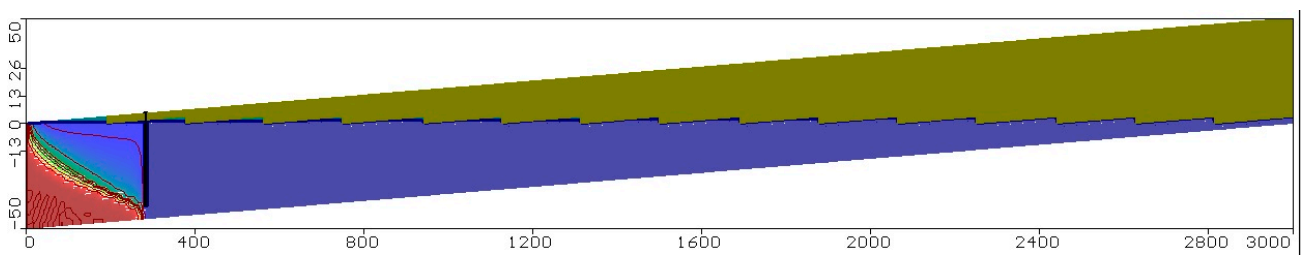

(h)

Figure A4. Saltwater distribution (in $\mathrm{mg} / \mathrm{L}$ ) in the Akrotiri aquifer for (a) the steady state and embedded barrier wall with $X_{b} / L_{o}=0.6$ and $(\mathbf{b}) d_{b} / d=0.2,(\mathbf{c}) d_{b} / d=0.3,(d) d_{b} / d=0.4,(e) d_{b} / d=0.5,(f) d_{b} / d=0.6$, (g) $d_{b} / d=0.7$ and (h) $d_{b} / d=0.8$.

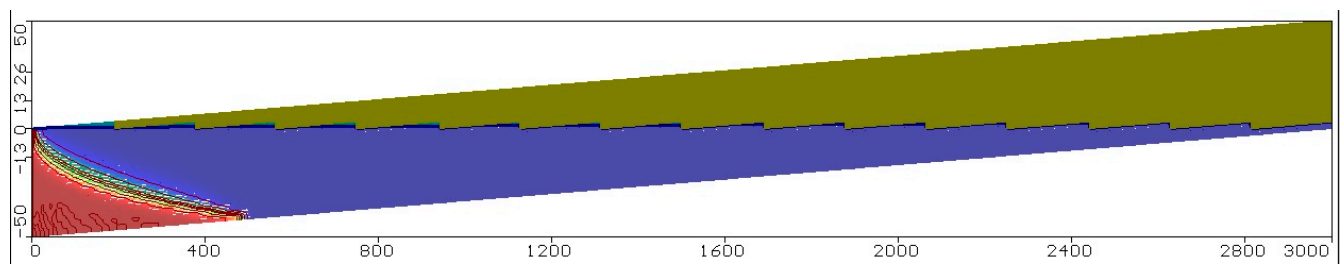

(a)

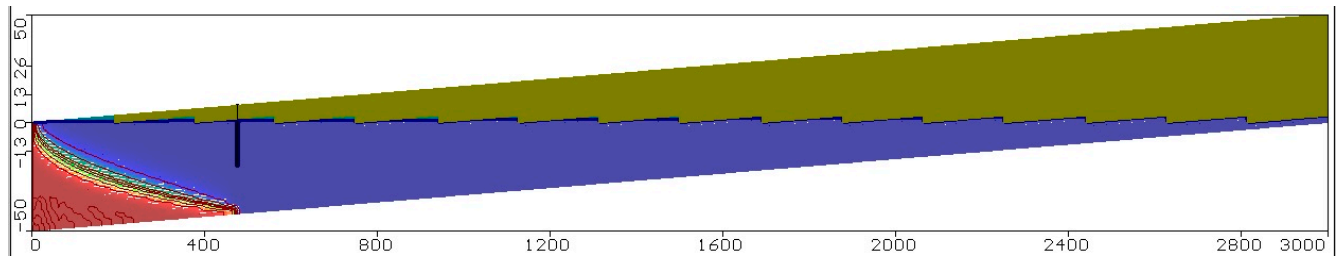

(b)

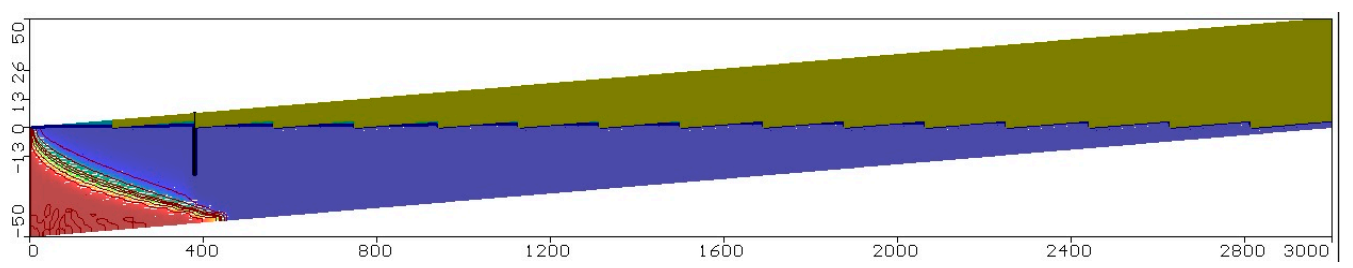

(c)

Figure A5. Cont. 


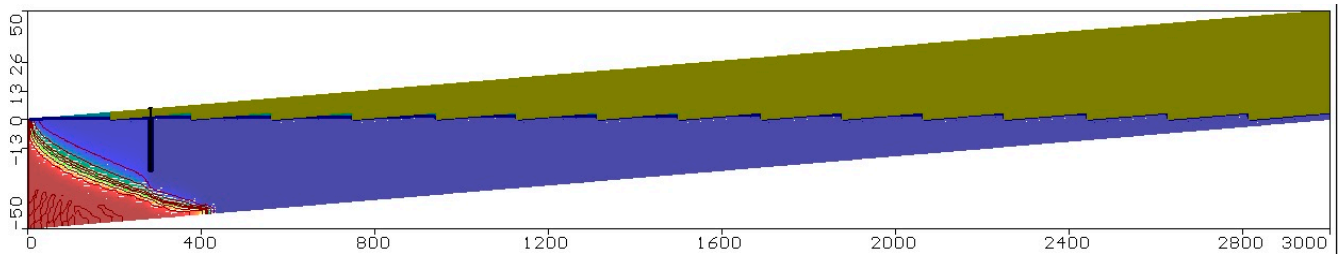

(d)

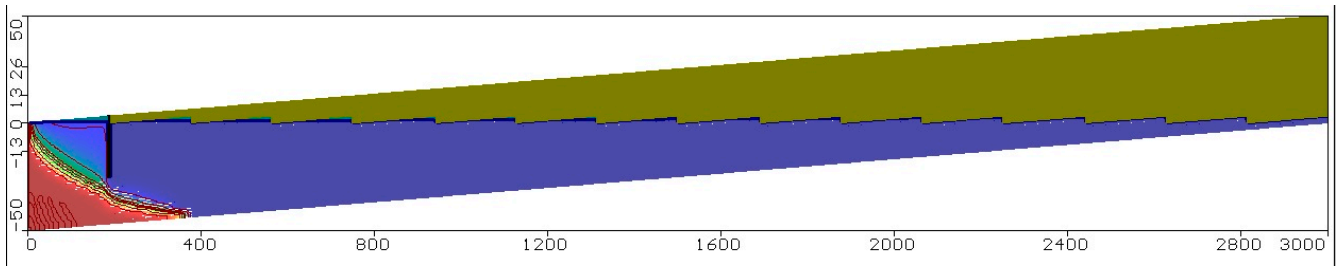

(e)

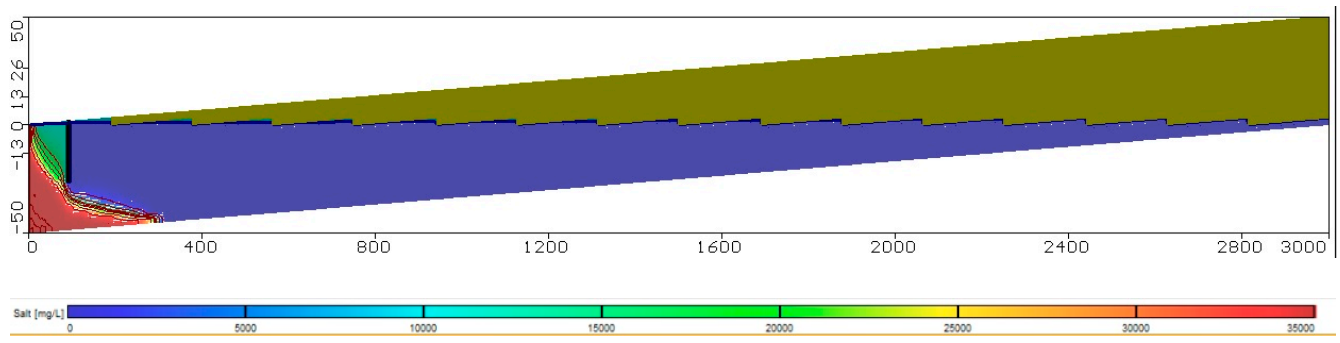

(f)

Figure A5. Saltwater distribution (in $\mathrm{mg} / \mathrm{L}$ ) in the Akrotiri aquifer for (a) the steady state and embedded barrier wall with $\mathrm{d}_{\mathrm{b}} / \mathrm{d}=0.5$ and (b) $\mathrm{X}_{\mathrm{b}} / \mathrm{L}_{\mathrm{o}}=1.0$, (c) $\mathrm{X}_{\mathrm{b}} / \mathrm{L}_{\mathrm{o}}=0.8,(\mathrm{~d}) \mathrm{X}_{\mathrm{b}} / \mathrm{L}_{\mathrm{o}}=0.6,(\mathbf{e}) \mathrm{X}_{\mathrm{b}} / \mathrm{L}_{\mathrm{o}}=0.4$ and (f) $\mathrm{X}_{\mathrm{b}} / \mathrm{L}_{\mathrm{o}}=0.2$.

\section{References}

1. Obikoya, I.B.; Bennell, J.D. Geophysical investigation of the fresh-saline water interface in the coastal area of Abergwyngregyn. In 21st EEGS Symposium on the Application of Geophysics to Engineering and Environmental Problems; European Association of Geoscientists \& Engineers: Amsterdam, The Netherlands, 2008; p. cp-177.

2. Purnama, S.; Marfai, M.A. Saline water intrusion toward groundwater: Issues and its control. J. Nat. Resour. Dev. 2012, 2. [CrossRef]

3. Jiménez-Madrid, A.; Castaño, S.; Vadillo, I.; Martinez, C.; Carrasco, F.; Soler, A. Applications of hydro-chemical and isotopic tools to improve definitions of groundwater catchment zones in a karstic aquifer: A case study. Water 2017, 9, 595. [CrossRef]

4. Baba, A.; Tayfur, G. Groundwater contamination and its effect on health in Turkey. Environ. Monit. Assess. 2011, 183, 77-94. [CrossRef]

5. Alcaraz, R.; Graniel, E.; Castro, A.F.; Vadillo, I. Assessment of groundwater contamination in Yucatan Peninsula (Mexico) by geostatistical analysis. Environ. Earth Sci. 2015. [CrossRef]

6. Vadillo, I.; Andreo, B.; Carrasco, F. Groundwater contamination by landfill leachates in a karstic aquifer. Water Air Soil Pollut. 2005. [CrossRef]

7. Wu, Y.-X.; Yang, T.-L.; Li, P.-C.; Lin, J.-X. Investigation of Groundwater Withdrawal and Recharge Affecting Underground Structures in the Shanghai Urban Area. Sustainability 2019, 11, 7162. [CrossRef]

8. Awadh, S.M.; Al-Mimar, H.; Yaseen, Z.M. Groundwater availability and water demand sustainability over the upper mega aquifers of Arabian Peninsula and west region of Iraq. Environ. Dev. Sustain. 2020, 1-21, in press. [CrossRef]

9. Aziz, S.A.; Zeleňáková, M.; Mésároš, P.; Purcz, P.; Abd-Elhamid, H. Assessing the Potential Impacts of the Grand Ethiopian Renaissance Dam on Water Resources and Soil Salinity in the Nile Delta, Egypt. Sustainability 2019, 11, 7050. 
10. Chang, Q.; Zheng, T.; Zheng, X.; Zhang, B.; Sun, Q.; Walther, M. Effect of subsurface dams on saltwater intrusion and fresh groundwater discharge. J. Hydrol. 2019. [CrossRef]

11. Sulaiman, S.O.; Kamel, A.H.; Sayl, K.N.; Alfadhel, M.Y. Water resources management and sustainability over the Western desert of Iraq. Environ. Earth Sci. 2019, 78. [CrossRef]

12. Awadh, S.M. A preliminary assessment of the geochemical factors affecting groundwater and surface water quality around the rural communities in Al-Anbar, Western Desert of Iraq. Environ. Earth Sci. 2018, 77, 83. [CrossRef]

13. Cheng, A.H.-D.; Ouazar, D.; Bear, J.; Sorek, S.; Herrera, I. (Eds.) Seawater Intrusion in Coastal Aquifers-Concepts, Methods and Practices; Springer Science \& Business Media: Berlin, Germany, 1999; ISBN 9780874216561.

14. Luyun, R.A., Jr. Effects of Subsurface Physical Barrier and Artificial Recharge on Seawater Intrusion in Coastal Aquifers. A Dissertation Presented to the United Graduate School of Agricultural Sciences, Kagoshima University in Partial Fulfillment of the Requirements for the Degree of Doctor of Philosophy. Available online: http://hdl.handle.net/10232/15057 (accessed on 1 January 2010).

15. Awadh, S.M.; Abdulhussein, F.M.; Al-Kilabi, J.A. Hydrogeochemical processes and water-rock interaction of groundwater in Al-Dammam aquifer at Bahr Al-Najaf, Central Iraq. Iraqi Bull. Geol. Min. 2016, 12, 1-15.

16. Bhagat, S.K.; Tiyasha, T.; Tung, T.M.; Mostafa, R.R.; Yaseen, Z.M. Manganese (Mn) removal prediction using extreme gradient model. Ecotoxicol. Environ. Saf. 2020, 204, 111059. [CrossRef] [PubMed]

17. Tung, T.M.; Yaseen, Z.M. A survey on river water quality modelling using artificial intelligence models: 2000-2020. J. Hydrol. 2020, 585, 124670.

18. Klassen, J.; Allen, D.M. Assessing the risk of saltwater intrusion in coastal aquifers. J. Hydrol. 2017. [CrossRef]

19. Motevalli, A.; Moradi, H.R.; Javadi, S. A Comprehensive evaluation of groundwater vulnerability to saltwater up-coning and sea water intrusion in a coastal aquifer (case study: Ghaemshahr-juybar aquifer). J. Hydrol. 2018. [CrossRef]

20. Stocker, T.F.; Qin, D.; Plattner, G.K.; Tignor, M.; Allen, S.K.; Boschung, J.; Midgley, P.M. Contribution of working group I to the fifth assessment report of the intergovernmental panel on climate change. Clim. Chang. 2013. [CrossRef]

21. Qutbudin, I.; Shiru, M.S.; Sharafati, A.; Ahmed, K.; Al-Ansari, N.; Yaseen, Z.M.; Shahid, S.; Wang, X. Seasonal Drought Pattern Changes Due to Climate Variability: Case Study in Afghanistan. Water 2019, 11, 1096. [CrossRef]

22. Pinder, G.F. Groundwater hydrology. In Groundwater Quantity and Quality Management; American Society of Civil Engineers: Reston, VI, USA, 2011; ISBN 9780784476222.

23. Van Dam, J.C. Exploitation, Restoration and Management. In Seawater Intrusion in Coastal Aquifers-Concepts, Methods and Practices; Springer Science \& Business Media: Berlin, Germany, 1999; pp. 73-125.

24. Oude Essink, G.H.P. Improving fresh groundwater supply-Problems and solutions. Ocean Coast. Manag. 2001, 44, 429-449. [CrossRef]

25. Robinson, G.; Ahmed, A.A.; Hamill, G.A. Experimental saltwater intrusion in coastal aquifers using automated image analysis: Applications to homogeneous aquifers. J. Hydrol. 2016. [CrossRef]

26. Mantoglou, A. Pumping management of coastal aquifers using analytical models of saltwater intrusion. Water Resour. Res. 2003, 39. [CrossRef]

27. Mantoglou, A.; Papantoniou, M. Optimal design of pumping networks in coastal aquifers using sharp interface models. J. Hydrol. 2008. [CrossRef]

28. Luyun, R.; Momii, K.; Nakagawa, K. Effects of Recharge Wells and Flow Barriers on Seawater Intrusion. Ground Water 2011, 49, 239-249. [CrossRef]

29. Vystavna, Y.; Schmidt, S.I.; Diadin, D.; Rossi, P.M.; Vergeles, Y.; Erostate, M.; Yermakovych, I.; Yakovlev, V.; Knöller, K.; Vadillo, I. Multi-tracing of recharge seasonality and contamination in groundwater: A tool for urban water resource management. Water Res. 2019. [CrossRef]

30. Vandenbohede, A.; Lebbe, L.; Van Houtte, E. Artificial recharge of fresh water in the Belgian coastal dunes. In Proceedings of the 20th Salt Water Intrusion Meeting (SWIM-20), Naples, FL, USA, 23-27 June 2008; pp. 282-285.

31. Vandenbohede, A.; Van Houtte, E.; Lebbe, L. Groundwater flow in the vicinity of two artificial recharge ponds in the Belgian coastal dunes. Hydrogeol. J. 2008. [CrossRef] 
32. Armanuos, A.M.; Ibrahim, M.G.; Mahmod, W.E.; Takemura, J.; Yoshimura, C. Analysing the Combined Effect of Barrier Wall and Freshwater Injection Countermeasures on Controlling Saltwater Intrusion in Unconfined Coastal Aquifer Systems. Water Resour. Manag. 2019, 33, 1265-1280. [CrossRef]

33. Armanuos, A.M.; Al-Ansari, N.; Yaseen, Z.M. Assessing the Effectiveness of Using Recharge Wells for Controlling the Saltwater Intrusion in Unconfined Coastal Aquifers with Sloping Beds: Numerical Study. Sustainability 2020, 12, 2685. [CrossRef]

34. Lu, C.; Werner, A.D.; Simmons, C.T.; Robinson, N.I.; Luo, J. Maximizing Net Extraction Using an InjectionExtraction Well Pair in a Coastal Aquifer. Groundwater 2013. [CrossRef]

35. Ibrahim, O.S.; Awadh, S.M.; Merkel, H.B.J.; Al, J.A.J.M.Z. Natural Attenuation Modelling of Heavy-Metal in Groundwater of Kirkuk City, Iraq. Iraqi J. Sci. 2016, 57, 2043-2061.

36. Luyun, R.; Momii, K.; Nakagawa, K. Laboratory-scale saltwater behavior due to subsurface cutoff wall. J. Hydrol. 2009, 377, 227-236. [CrossRef]

37. Mahesha, A. Conceptual Model for the Safe Withdrawal of Freshwater from Coastal Aquifers. J. Environ. Eng. 2009, 135, 980-988. [CrossRef]

38. Ataie-Ashtiani, B.; Ketabchi, H. Elitist continuous ant colony optimization algorithm for optimal management of coastal aquifers. Water Resour. Manag. 2011, 25, 165-190. [CrossRef]

39. Pool, M.; Carrera, J. A correction factor to account for mixing in Ghyben-Herzberg and critical pumping rate approximations of seawater intrusion in coastal aquifers. Water Resour. Res. 2011, 47. [CrossRef]

40. Ketabchi, H.; Ataie-Ashtiani, B. Evolutionary algorithms for the optimal management of coastal groundwater: A comparative study toward future challenges. J. Hydrol. 2015, 520, 193-213. [CrossRef]

41. Abd-Elhamid, H.F.; Javadi, A.A. A Cost-Effective Method to Control Seawater Intrusion in Coastal Aquifers. Water Resour. Manag. 2011, 25, 2755-2780. [CrossRef]

42. Javadi, A.; Hussain, M.; Sherif, M.; Farmani, R. Multi-objective Optimization of Different Management Scenarios to Control Seawater Intrusion in Coastal Aquifers. Water Resour. Manag. 2015. [CrossRef]

43. Anwar, H.O. The effect of a subsurface barrier on the conservation of freshwater in coastal aquifers. Water Res. 1983, 17, 1257-1265. [CrossRef]

44. Basri, M.H. Two New Methods for Optimal Design of Subsurface Barrier to Control Seawater Intrusion. Ph.D. Thesis, University of Manitoba, Winnipeg, MB, Canada, 2001.

45. Abdoulhalik, A.; Ahmed, A.; Hamill, G.A. A new physical barrier system for seawater intrusion control. J. Hydrol. 2017, 549, 416-427. [CrossRef]

46. Kaleris, V.K.; Ziogas, A.I. The effect of cutoff walls on saltwater intrusion and groundwater extraction in coastal aquifers. J. Hydrol. 2013, 476, 370-383. [CrossRef]

47. Abdoulhalik, A.; Ahmed, A.A. The effectiveness of cutoff walls to control saltwater intrusion in multi-layered coastal aquifers: Experimental and numerical study. J. Environ. Manag. 2017, 199, 62-73. [CrossRef] [PubMed]

48. Allow, K.A. The use of injection wells and a subsurface barrier in the prevention of seawater intrusion: A modelling approach. Arab. J. Geosci. 2012, 5, 1151-1161. [CrossRef]

49. Lu, C.; Xin, P.; Kong, J.; Li, L.; Luo, J. Analytical solutions of seawater intrusion in sloping confined and unconfined coastal aquifers. Water Resour. Res. 2016, 52, 6989-7004. [CrossRef]

50. Hanson, G.; Nilsson, A. Ground-Water Dams for Rural-Water Supplies in Developing Countries. Ground Water 1986, 24, 497-506. [CrossRef]

51. Sherif, M.M.; Singh, V.P. Effect of climate change on sea water intrusion in coastal aquifers. Hydrol. Process. 1999, 13, 1277-1287. [CrossRef]

52. Koussis, A.D.; Mazi, K.; Destouni, G. Analytical single-potential, sharp-interface solutions for regional seawater intrusion in sloping unconfined coastal aquifers, with pumping and recharge. J. Hydrol. 2012, 416, 1-11. [CrossRef]

53. Yechieli, Y.; Shalev, E.; Wollman, S.; Kiro, Y.; Kafri, U. Response of the Mediterranean and Dead Sea coastal aquifers to sea level variations. Water Resour. Res. 2010, 46. [CrossRef]

54. Mushtaha, A.M.; Van Camp, M.; Walraevens, K. Evolution of runoff and groundwater recharge in the Gaza Strip over the last four decades. Environ. Earth Sci. 2019, 78. [CrossRef]

55. Alfarrah, N.; Walraevens, K. Groundwater Overexploitation and Seawater Intrusion in Coastal Areas of Arid and Semi-Arid Regions. Water 2018, 10, 143. [CrossRef] 
56. Ghazaw, Y.M.; Ghumman, A.R.; Al-Salamah, I.; Khan, Q.U.Z. Investigations of Impact of Recharge Wells on Groundwater in Buraydah by Numerical Modeling. Arab. J. Sci. Eng. 2013, 39, 713-724. [CrossRef]

57. Du, Y.; Ma, T.; Chen, L.; Shan, H.; Xiao, C.; Lu, Y.; Liu, C.; Cai, H. Genesis of salinized groundwater in Quaternary aquifer system of coastal plain, Laizhou Bay, China: Geochemical evidences, especially from bromine stable isotope. Appl. Geochem. 2015, 59, 155-165. [CrossRef]

58. Weyer, K.U. The case of the Biscayne Bay and aquifer near Miami, Florida: Density-driven flow of seawater or gravitationally driven discharge of deep saline groundwater? Environ. Earth Sci. 2017, 77. [CrossRef]

59. Sappa, G.; Iacurto, S.; Ferranti, F.; De Filippi, F.M. Groundwater Quality Assessment in a Karst Coastal Region of the West Aurunci Mountains (Central Italy). Geofluids 2019, 2019, 1-14. [CrossRef]

60. Qu, F.; Lu, Z.; Zhang, Q.; Bawden, G.W.; Kim, J.-W.; Zhao, C.; Qu, W. Mapping ground deformation over Houston-Galveston, Texas using multi-temporal InSAR. Remote Sens. Environ. 2015, 169, 290-306. [CrossRef]

61. Nigate, F.; Van Camp, M.; Yenehun, A.; Belay, A.S.; Walraevens, K. Recharge-Discharge Relations of Groundwater in Volcanic Terrain of Semi-Humid Tropical Highlands of Ethiopia: The Case of Infranz Springs, in the Upper Blue Nile. Water 2020, 12, 853. [CrossRef]

62. Andreasen, D.C.; Nardi, M.R.; Staley, A.W.; Achmad, G.; Grace, J.W. The Maryland Coastal Plain Aquifer Information System: A GIS-based tool for assessing groundwater resources. Geol. Soc. Am. Spec. Pap. 2016, 520, 159-170.

63. Benham, G.; Frolkovic, P.; Ivanov, T.; Mondal, R.; Mondal, S.; Rottschafer, V.; Kaouri, K. Mathematical modelling of the Germasogeia aquifer. In Proceedings of the 125th European Study Group with Industry (ESGI125), Cyprus, Limassol, 5-9 December 2016; Mathematics for Industry Network: Limassol, Cyprus, 2017.

64. Greggio, N.; Mollema, P.; Antonellini, M.; Gabbianelli, G. Irrigation Management in Coastal Zones to Prevent Soil and Groundwater Salinization. Resour. Manag. Sustain. Agric. 2012, 10, 50534.

65. Kennedy, C.D.; Genereux, D.P. 14C Groundwater Age and the Importance of Chemical Fluxes Across Aquifer Boundaries in Confined Cretaceous Aquifers of North Carolina, USA. Radiocarbon 2007, 49, 1181-1203. [CrossRef]

66. Guo, W.; Langevin, C.D. User's Guide to SEAWAT: A Computer Program for Simulation of Three-Dimensional Variable-Density Ground-Water Flow; USGS Publications Warehouse: Reston, VA, USA, 2002; ISBN 0607992573.

67. Simpson, M.J.; Clement, T.P. Theoretical analysis of the worthiness of Henry and Elder problems as benchmarks of density-dependent groundwater flow models. Adv. Water Resour. 2003, 26, 17-31. [CrossRef]

68. Simpson, M.J.; Clement, T.P. Improving the worthiness of the Henry problem as a benchmark for density-dependent groundwater flow models. Water Resour. Res. 2004, 40. [CrossRef]

69. Langevin, C.D.; Thorne, D.T., Jr.; Dausman, A.M.; Sukop, M.C.; Guo, W. SEAWAT Version 4: A Computer Program for Simulation of Multi-Species Solute and Heat Transport. Geol. Surv. 2008. [CrossRef]

70. Bhagat, S.K.; Tung, T.M.; Yaseen, Z.M. Development of artificial intelligence for modeling wastewater heavy metal removal: State of the art, application assessment and possible future research. J. Clean. Prod. 2020, 250, 119473. [CrossRef]

(C) 2020 by the authors. Licensee MDPI, Basel, Switzerland. This article is an open access article distributed under the terms and conditions of the Creative Commons Attribution (CC BY) license (http://creativecommons.org/licenses/by/4.0/). 